\title{
Glycoconjugates in host-helminth interactions
}

\section{Nina Salinger Prasanphanich, Megan L. Mickum, Jamie Heimburg-Molinaro and Richard D. Cummings*}

Department of Biochemistry, Glycomics Center of Emory University, Emory University School of Medicine, Atlanta, GA, USA

\section{Edited by:}

Paul A. Ramsland, Burnet Institute,

Australia

Reviewed by:

Andrew Tasman Hutchinson,

University of Technology Sydney,

Australia

Geanncarlo Lugo-Villarino, Institut de

Pharmacologie et de Biologie

Structurale, France

\section{*Correspondence.}

Richard D. Cummings, Department of

Biochemistry, Glycomics Center of

Emory University, Emory University

School of Medicine, 1510 Clifton Road

\#4001, Atlanta, GA 30322, USA

e-mail: rdcummi@emory.edu
Helminths are multicellular parasitic worms that comprise a major class of human pathogens and cause an immense amount of suffering worldwide. Helminths possess an abundance of complex and unique glycoconjugates that interact with both the innate and adaptive arms of immunity in definitive and intermediate hosts. These glycoconjugates represent a major untapped reservoir of immunomodulatory compounds, which have the potential to treat autoimmune and inflammatory disorders, and antigenic glycans, which could be exploited as vaccines and diagnostics. This review will survey current knowledge of the interactions between helminth glycans and host immunity and highlight the gaps in our understanding which are relevant to advancing therapeutics, vaccine development, and diagnostics.

Keywords: glycans, glycoconjugates, helminths, C-type lectin, innate immunity, adaptive immunity, anti-glycan antibodies, schistosomiasis

\section{INTRODUCTION}

Helminths are multicellular parasitic worms that comprise a major class of human pathogens. They rely on a host species to complete a portion of their life cycle, which results in significant morbidity for human and animal hosts. The three classes of helminths - nematodes, trematodes, and cestodes - account for half of the WHOdesignated "Neglected Tropical Diseases," and infect 1-2 billion of the world's poorest people, with soil-transmitted helminths (gastrointestinal nematodes including Ascaris, Trichuris, Necator sp.) and schistosomes (blood-dwelling trematodes) being the most common (1-3). Although great strides have been made through implementation of chemotherapy and improved sanitation, massive amounts of suffering due to helminth infections persist, and to date, no vaccines for helminths or any human parasite exist.

The symptoms of helminth infection depend on infection intensity (i.e., number of worms and/or eggs), and range from none to chronic disease, disfigurement, and death. The majority of cases in endemic regions manifest with low-level symptoms such as anemia, malnutrition, and delayed physical/cognitive development $(1,4)$. The estimated disease burden of helminth infection is at least 13,000,000 DALYs (years of life and productive life lost due to disability and/or death) (2). However, this is probably a gross underestimation of the total disease burden because several common helminth infections are excluded, and DALYs fail to account for the social and economic consequences caused by the subtler symptoms mentioned above $(1,5,6)$. Some estimates therefore rank the burden of helminth infection even higher than that of malaria or HIV/AIDS, making helminths a true "societal poverty trap" $(4,7,8)$.

While a substantial body of literature on the biology and immunology of helminth infection exists, the science has yet to translate into more sophisticated solutions for diagnosis, treatment, or prevention. This stems from a poor understanding of protective immunological mechanisms, insufficient knowledge of unique molecular structures of helminths, and a lack of innovative vaccine strategies to protect against complex, multicellular pathogens. The complex carbohydrates of helminths present an exciting opportunity to fill these gaps. Many glycans within glycoproteins and glycolipids are unique to helminths or to a particular worm species, they are abundant on worm surfaces and secretions, and humans vigorously target these glycans in the natural immune response. Helminth glycans also have potent immunomodulatory effects. Advances in glyco-technology have steadily increased our ability to understand this often-overlooked area of host-pathogen interactions. In this review, we will discuss the role of carbohydrates in helminth innate and adaptive immunity, highlight glycan structures of interest, and call attention to progress in exploiting these structures for modulation of autoimmune/atopic diseases and better control of helminth infection.

\section{THE INTERFACE OF HELMINTHS AND THEIR HOSTS}

Each human helminth has a complex, multi-stage lifecycle, which depends on particular intermediate and definitive hosts and an ecological niche. For example, S. mansoni, the most common cause of schistosomiasis, lives only in fresh water inhabited by the mollusk host Biomphalaria glabrata. Its eggs hatch into miracidia which penetrate susceptible snails. The miracidia circulate in the snail hemolymph and transform into sporocysts, which over the course of about a month generate free-swimming cercariae that exit the snail $(9,10)$. Cercariae penetrate the skin of a human host or other mammals exposed to water harboring infected snails. In the process, they are transformed into schistosomula larvae, which, after a few days in the dermis, make their way into the venous circulation. Within 1-3 weeks they traverse the narrow pulmonary capillary beds and move to the portal vessels, feeding on blood, and growing in size as they move. Male and female worm pairs mate and migrate up the mesenteric vein, where they commence egg laying, about 5-6 weeks after initial infection. Eggs 
excreted into the stool continue the schistosome life cycle if they are deposited back into fresh water, while others become trapped in the intestinal walls and liver (11). Other mammals are also infected by schistosomes and serve as major reservoirs of transmission (12). Hookworms, by contrast, such as Necator americanus and Ancylostoma duodenale, have only humans as their definitive host (4). The larvae live freely in the soil for a short period of time while they develop to the L3 stage larvae, which, like schistosomes, penetrate the skin, and migrate into the vasculature. Upon reaching the lungs, they migrate up to the pharynx, at which point they are swallowed. The larvae molt, and male and female adult worms embed in the mucosa and submucosa of the intestines in order to mate and feed on blood $(7,9)$. Helminths can live for years to decades in a human host, continuously producing eggs.

The helminth's interface with host immunity is equally complicated. Nematodes are protected by a layer of collagen that comprises the cuticle, which is overlain by a lipid-rich epicuticle and a glycoprotein surface coat. The cuticle is re-synthesized and shed every time the worm enters a new developmental stage (13). The surface of the schistosome is complex, incompletely understood, and variable throughout its life stages. The outer layer consists of a tegument, a syncytial layer of cells which are bounded apically by a complex invaginated membrane (14). The tegument is comprised of secreted lipid-rich "membranocalyx," as well as "glycocalyx," the latter of which is partially discarded upon transformation of cercariae to schistosomules, but also appears to be prominent on the surface of adult worms (15-18). The expression of both proteins and glycans is regulated from one life stage to the next, and highly variable $(19,20)$. The surface of the worms as well as excreted and secreted products, molted tissue layers, and eggs make up the targets for immune recognition and attack. The gastrointestinal (GI) tract of blood-feeding worms like schistosomes and hookworms is also exposed to antibodies $(21,22)$.

\section{GLYCANS OF SCHISTOSOMES AND OTHER PARASITIC HELMINTHS}

Parasitic helminths are characterized by their production of many different glycoproteins, containing complex $\mathrm{N}$ - and $\mathrm{O}$-glycans, and glycolipids; all of these glycans are unusual and structurally distinct from host glycans (some are depicted in Table 1). For example, helminths, such as $S$. mansoni, neither synthesize sialic acid nor acquire it from their hosts, whose glycans typically terminate in sialic acid (23). Helminth glycans commonly terminate with $\beta$-linked GalNAc (24-27), often in the sequence GalNAc $\beta 1-4 G l c N A c$ (termed the LacdiNAc motif, LDN), which is not commonly present in vertebrate glycans $(28,29)$. In addition, many helminths use unusual sugars, such as tyvelose, found in N-glycans of Trichinella spiralis (30-32), which may be useful in both resistance to infection (33) and diagnostics $(34,35)$. Several helminths also generate unusual modifications of sugars, such as the phosphorylcholine (PC) modification of glycans of Echinococcus granulosus, several other parasitic nematodes, and the free-living Caenorhabditis elegans [(36-41); and reviewed in (42)], and 2-O-methylation of fucose and 4-O-methylation of galactose in highly antigenic glycans of $T$. canis $(43,44)$. In $S$. mansoni glycans, unique additions of fucose residues are seen on both GlcNAc and GalNAc residues in the LDN motif, giving rise to FLDN, LDNF, poly-LDNF, DF-LDN-DF (27, 45-51), as well as unique fucose/xylose modifications of the $N$-glycan core $(23,52,53)$ (Table 1). Some nematodes, of which C. elegans is best studied, also oddly modify their core fucose residues with galactose (54-58). Interestingly, only the trematode S. mansoni (59-61) and the cattle lungworm nematode Dictyocaulus viviparous (62) have been shown to synthesize glycans containing the terminal motif of the Lewis $\mathrm{x}$ (Lex) antigen, variants of which are also expressed commonly on human cells $(61,63)$. Schistosomes synthesize novel glucuronate-containing glycans on glycoproteins, such as the CAA structure $(64,65)$. The core structures of the glycolipids in helminths are also unlike those of mammals, such as the presence of the "schisto motif" GalNAc $\beta 1-4 \mathrm{Glc} \beta$-Cer (25) of S. mansoni, and the "arthro motif" Man $\beta 1-4$ Glc $\beta$-Cer of A. suum (66), instead of the mammalian "lacto motif" Gal $\beta 1-4 \mathrm{Glc} \beta$-Cer.

The unusual nature and antigenicity of parasitic helminth glycans belies the apparently commonly held belief among immunologists and parasitologists that parasites do not express antigenic glycans, but rather cloak themselves in parasite-synthesized and/or host-acquired antigens to avoid immune recognition in what has been termed "molecular mimicry" or "antigen sharing" $(67,68)$. This concept may no longer be tenable as a general description in regard to parasitic helminths, which synthesize few glycans resembling their vertebrate hosts. In fact, glycans constitute a major portion of the host's antigenic targets in several helminth infections. In non-human primate models of schistosomiasis, they appear to be even more highly targeted than proteins (69-74). When true molecular mimicry by infectious organisms does occur, such as the structural similarity between mammalian ganglioside GM1 and the terminal structure of the lipooligosaccharide from Campylobacter jejuni, the mimicry is associated with pathological autoimmunity, as seen in Guillain-Barré syndrome $(75,76)$. Interestingly, few of the antibodies to helminth glycans cross-react with host glycans. The only well-known example of this is Lex (63), suggesting that even helminth glycans sharing some features with rare mammalian glycoconjugates, such as LDN and LDNF (Table 1) are presented in a unique fashion on parasites. As discussed below, results of multiple studies indicate that parasites instead utilize "glycan gimmickry" (77), in which their glycans can interact with host receptors to modulate host immune responses to the benefit of the parasite.

\section{INNATE IMMUNE RESPONSES TO HELMINTH-DERIVED GLYCANS}

The response of an infected host to a parasitic helminth is multifaceted and involves both innate and adaptive immune factors, and a host of cellular responses. While this review section is devoted to mammalian responses to helminth infections, it is worth noting that other organisms have also developed a wide range of responses to helminth infections. For example, one lectin (CNL) from the mushroom Clitocybe nebularis (78) can bind to the LDN motif, and the recombinant form of the CNL can directly kill the hypersensitive C. elegans mutant strain pmk-1 (79). Other types of fungi, on which C. elegans feeds, express specific lectins that recognize the core galactose-fucose determinants (57). These are highly expressed on the worm's intestinal cells, and ingestion of such fungi causes death of the nematode (80). The zebrafish (Danio 


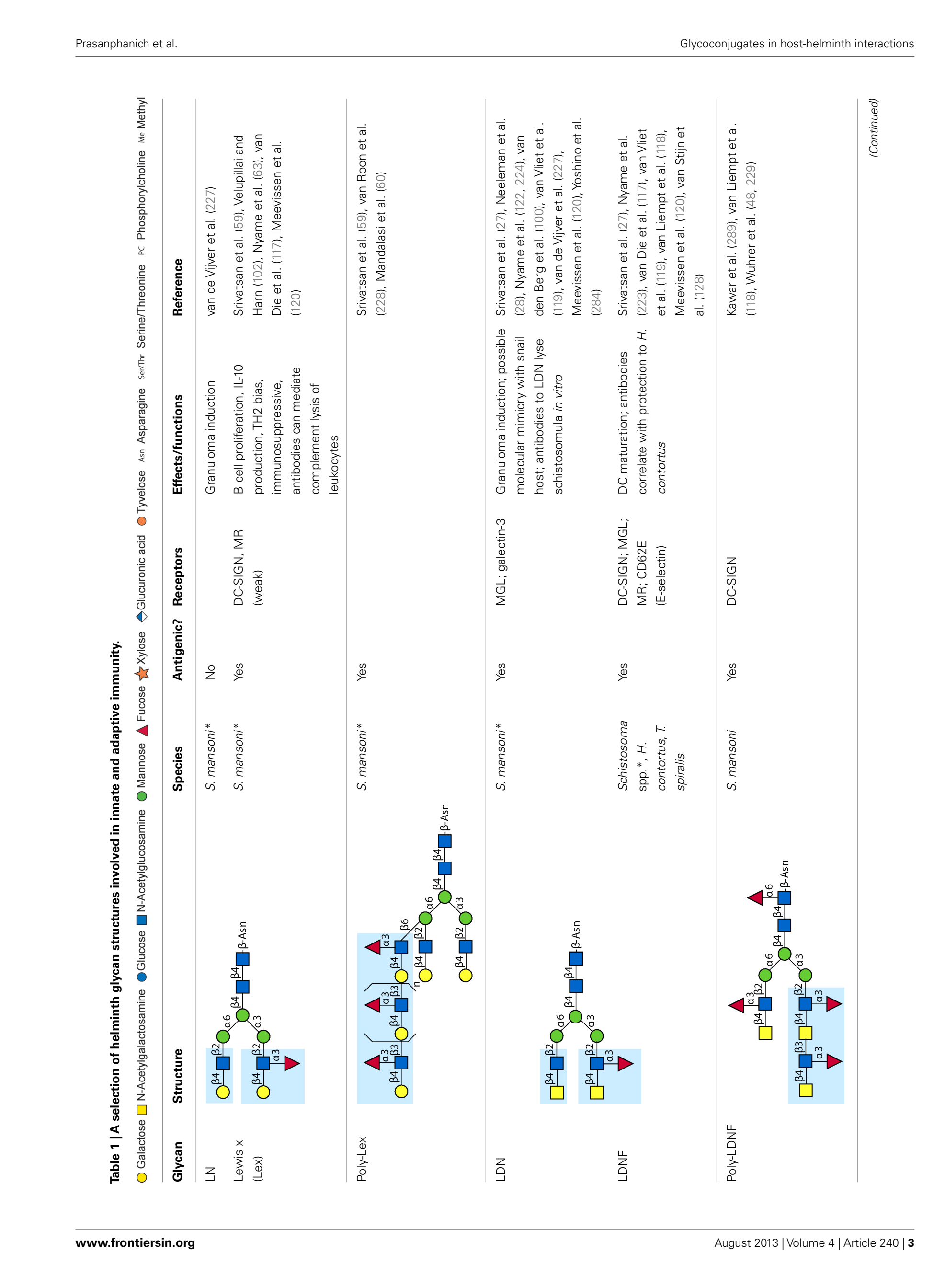




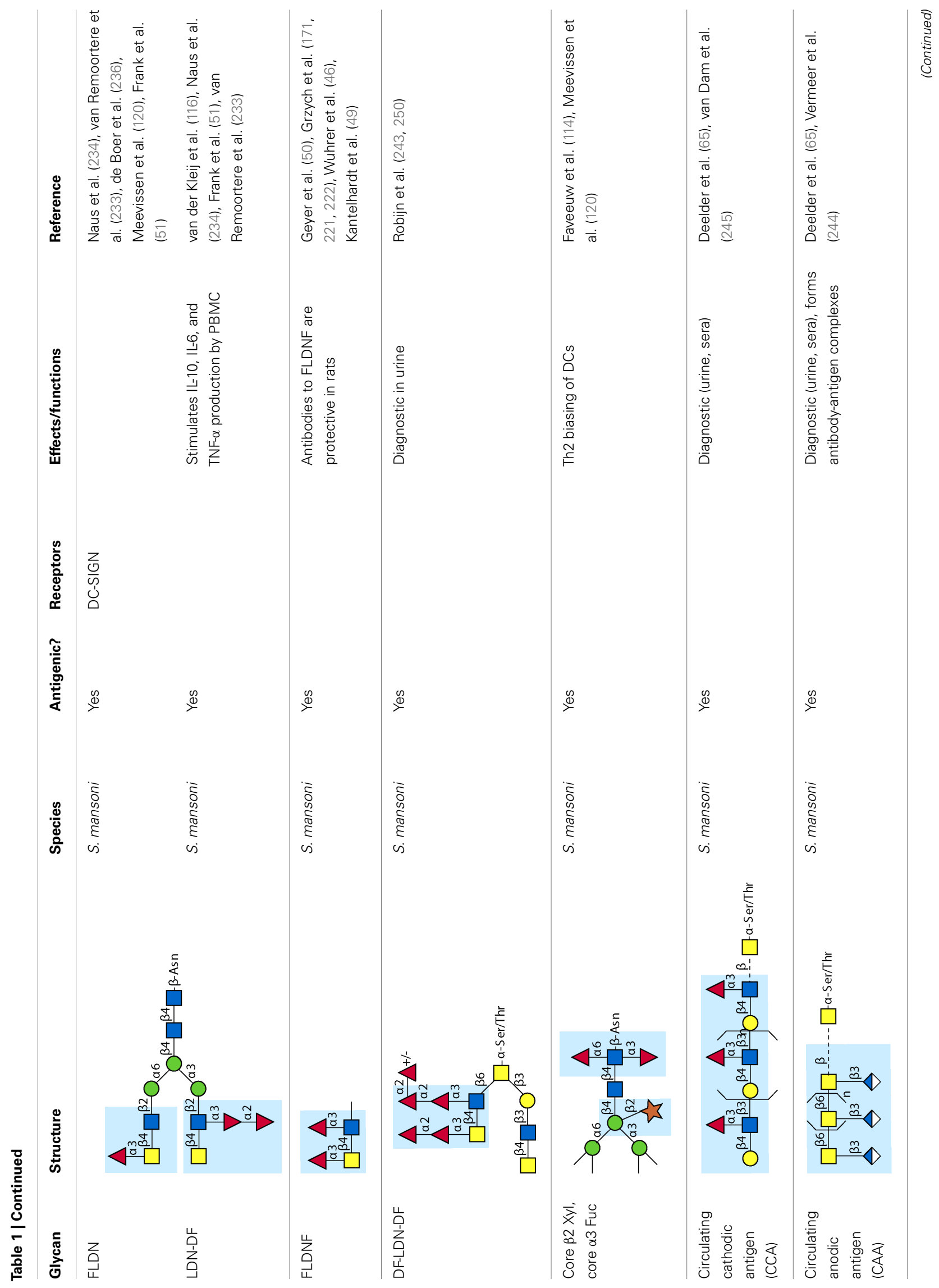




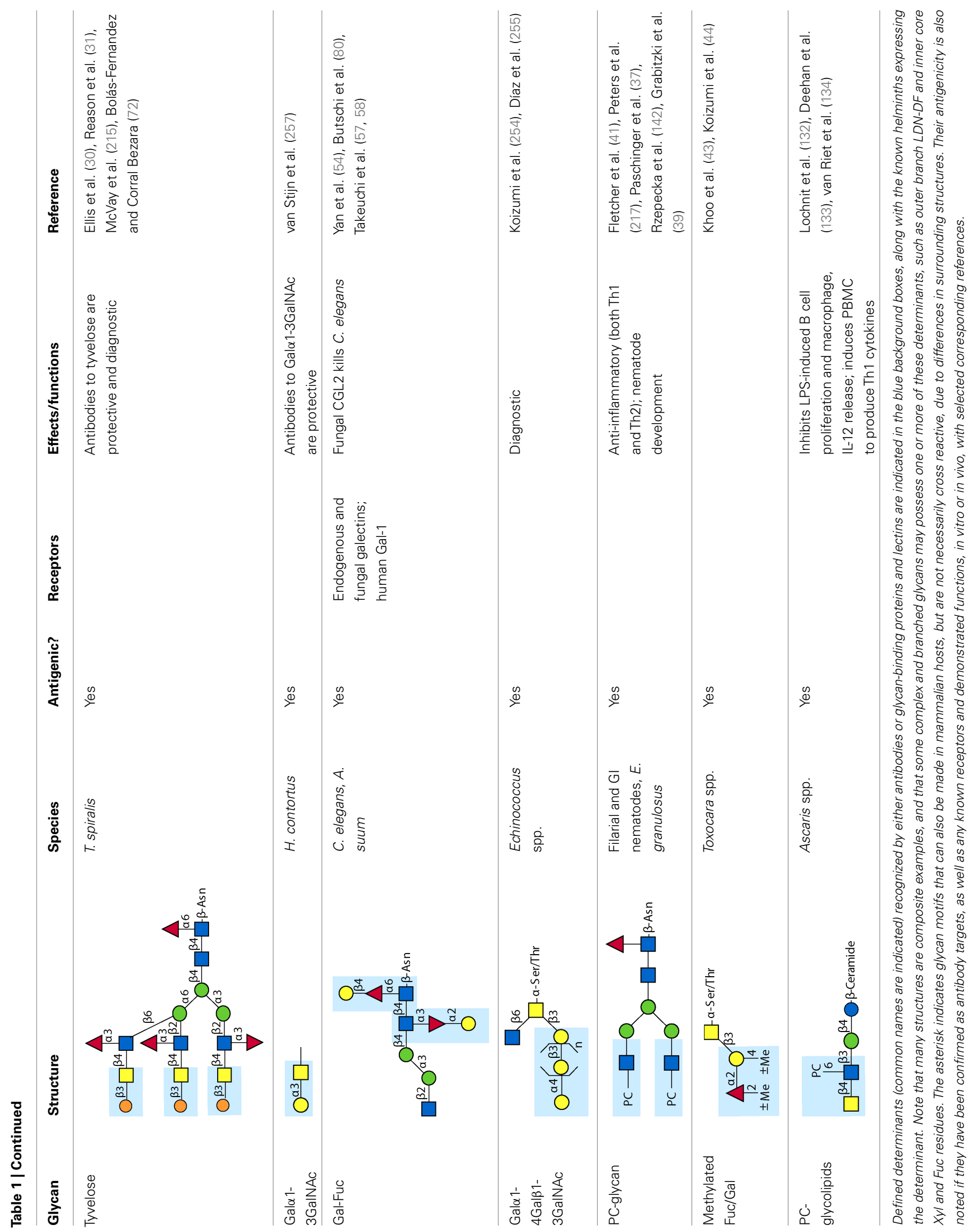


rerio) is parasitized by the pathogenic nematode Pseudocapillaria tomentosa (81). Similarly to human gastrointestinal worms, infection causes eosinophilic inflammation in the fish gut, offering a potentially promising new model with which to understand the interactions between helminth ligands and host innate immune receptors $(82,83)$.

Mammalian immune responses to parasitic helminths are incredibly complex. In some mammalian hosts, the adaptive response may help to prevent, limit, or eradicate the infection, while in others it appears ineffectual (84). The ability of adaptive effector mechanisms to limit or clear infection likely depends, in large part, on cues received from the innate response. The innate response can both limit the pathology of the infection and directly contribute to destruction and expulsion of worms. However, the parasites have evolved glycan gimmickry approaches to battle the host responses. Thus, the balance arrived at in a chronic infection may result in asymptomatic infection even though humans rarely clear all of the infecting organisms without treatment $(84,85)$.

Antigen-presenting cells (APCs) including dendritic cells (DCs) and macrophages $(M \Phi)$ initially encounter invading pathogens and are crucial for regulation of the type of adaptive immune response $(86,87)$ (Figure 1). Helminths induce effector cell generation consisting of Th2, T regulatory cells $\left(\mathrm{T}_{\text {regs }}\right)$, and alternatively activated (AA) MФ (88-91), which may contribute to the capacity of helminths to counteract inflammation associated with autoimmune disease. Recognition of pathogen glycans is known to be mediated by at least two classes of specialized pattern-recognition receptors (PRRs) on APC, the Toll-like receptors (TLRs) and C-type lectin receptors (CLRs), which are instrumental in regulation of adaptive immunity (92-94). There are over a dozen different C-type lectins expressed in DC and Langerhans cells, and many other glycan-binding proteins, such as selectins, siglecs, and galectins expressed by lymphocytes, all of which have potential to interact with parasite-derived glycans (95, 96). TLRs function as PRRs that can recognize a wide variety of foreign molecular patterns (pathogen-associated molecular patterns or PAMPs), as seen, for example, where they recognize the many variants of LPS. While CLRs can also function as PRRs, their specificity is often much more restricted, as seen with dectin-1, which is a receptor for $\beta$-glucan (97). The balance between CLR- and TLRmediated signals appears crucial to determine the balance between tolerance and immunity $(92,98,99)$. Human galectins- 1 and -3 have been shown to recognize the core galactosylated-fucose epitope that is expressed in nematodes and the LDN-motifs that are common in schistosomes, respectively, implying a role for galectins in pattern recognition of parasitic helminths $(58,100)$.

Little has been done on direct effects of intact worms on APC, and the mechanistic roles of glycans in glycan gimmickry, but several studies using soluble extracts of worms or their eggs have demonstrated the importance of helminth glycans in immunomodulation. Early observations showed that egg deposition was responsible for the Th2 character of chronic murine schistosomiasis (101). The Harn group followed up on these observations by showing that LNFPIII, a human milk sugar containing Lex, induced B cell proliferation and IL-10 production by murine spleen cells (102). They also demonstrated that intranasal administration of S. mansoni soluble egg antigen (SEA) extracts

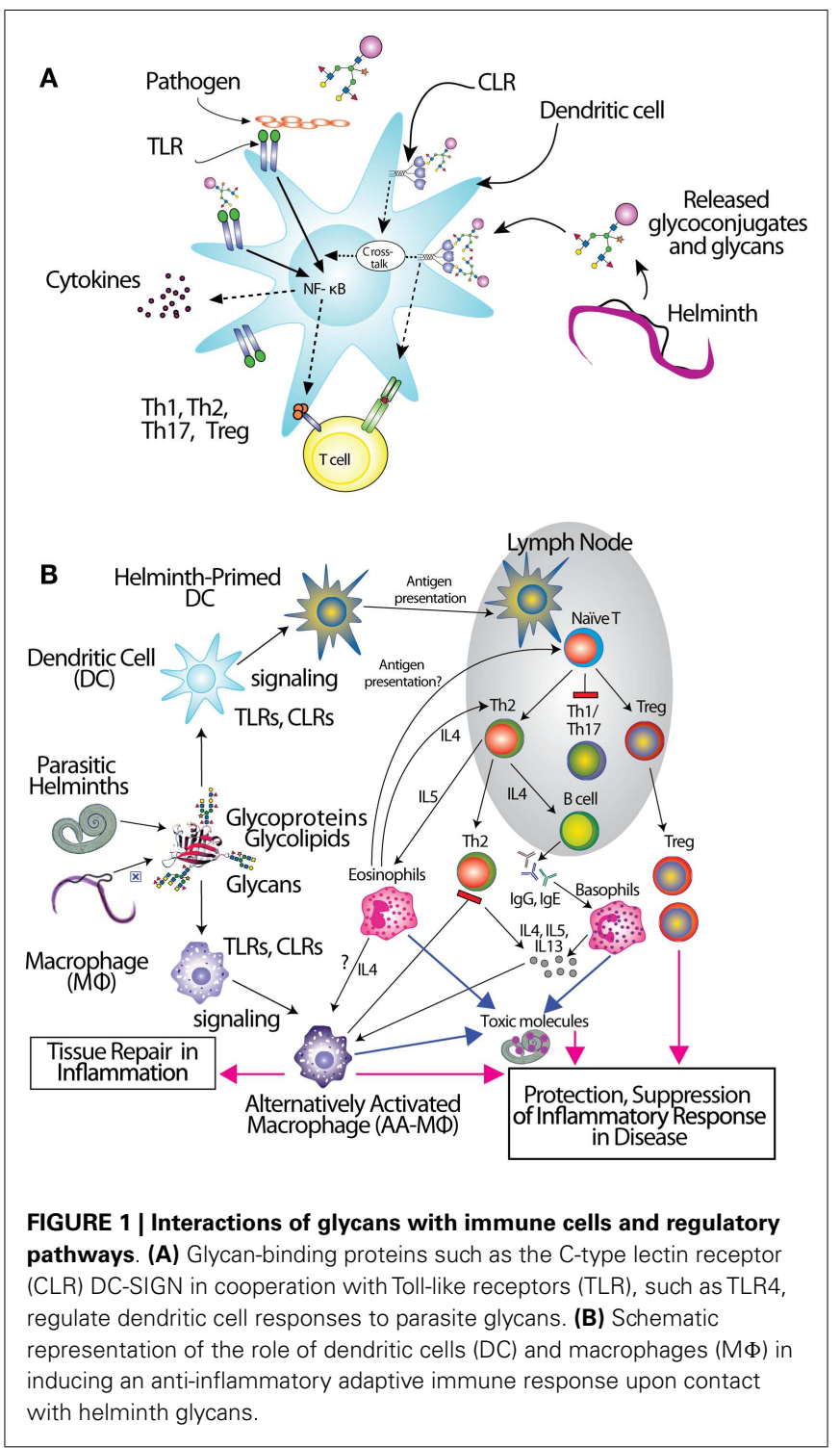

to mice promoted IgE and IgG1 production and induced secretion of IL-4, IL-5, and IL-10, but not IFN- $\gamma$, by lymphocytes $(103,104)$. These responses were completely dependent on the presence of intact helminth glycans, since partial oxidation of glycans with periodate abolished the ability of SEA to stimulate these Th2 responses (103). Both SEA and soluble worm proteins from Trichuris suis (TSWAP) inhibit LPS-induced secretion of many pro-inflammatory cytokines and chemokines from DC $(99,103,105)$. This suppressive effect was also periodate-sensitive, while protein denaturation at $80^{\circ} \mathrm{C}$, and digestion of the glycoproteins with chymotrypsin had no effect (106). In addition, coincubation of immature DC with LPS and helminth compounds induced a decrease of CD86 surface expression (99) and a strong upregulation of OX40L expression on the DC surface which was glycan-dependent $(105,106)$. Other studies showed that immunization of mice with soluble extracts of many different helminths, including C. elegans, the roundworm Brugia malayi, and the 
tapeworm Taenia crassiceps, also induced a glycan-dependent cytokine response biased toward Th2 cells (107-109). One of the glycan determinants which contributes to the Th2-biasing effect of SEA is Lex $(103,110-113)$, but other schistosome glycans can also induce Th2 biasing, such as core fucosylated/xylosylated $N$-glycans (114). The unique abilities of helminth glycolipids to drive Th2 bias may involve CD1d-restricted T cells (115). Treatment of monocytes with $S$. mansoni egg glycolipids, but not adult worm glycolipids, stimulated IL-10, IL-6, and TNF- $\alpha$ production, which was largely dependent on expression of the LDN-DF motif, indicating that helminth glycolipids can induce both pro- and anti-inflammatory cytokine secretion (116).

In regard to the mechanisms of glycan recognition, several CLRs of DC and M $\Phi$, such as DC-SIGN, bind selected glycans, including Lex, LDNF, and poly-LDNF $(117,118)$ on the defined glycan microarray from the Consortium for Functional Glycomics (CFG). Human MФ galactose-type lectin (MGL), expressed as an Fc fusion protein, binds to a subset of glycans on the CFG microarray, with highest recognition of those containing terminal GalNAc residues (119). Related studies using similar microarray approaches have also defined specific interactions of DC-SIGN, mannose receptor (MR), and MGL with schistosome-related glycans containing Lex motifs, LDN, LDNF, as well as core $\beta 2 X y l$ glycans (120). MGL is selectively expressed on APC with elevated levels on tolerogenic DC and AA-MФ (121), suggesting a role of MGL in the homeostatic control of adaptive immunity. This is consistent with earlier studies showing that DC-SIGN binds components within SEA of S. mansoni, as do the CLRs MR and MGL (99). SEA expresses many of the fucosylated glycans used in the microarray studies above. In particular, LDNF and Lex antigens are expressed on all intra-mammalian stages of the parasite $(27,59,122)$. We also confirmed the differential binding profile of DC-SIGN and MGL to SEA and TSWAP by ELISA (106).

The CLRs mentioned above induce endocytosis of bound molecules for antigen presentation but do not induce classical signs of APC activation. They do, however, modulate the gene transcription induced by other receptors (Figure 1A), such as NF- $\kappa$ B signaling downstream of TLRs (123). Interestingly, there is evidence that TLR4 may be involved in responses to $S$. mansoni Lexcontaining glycans (111), indicating interactions and co-signaling via TLR and CLR may contribute to the overall polarization of immunosuppressive responses to the parasite infections. Recent studies in DC reveal the capacity of some CLRs to induce intracellular signaling cascades upon binding to pathogen-derived glycans, and show that CLR-induced signals intersect with the signaling pathways of several TLRs, including TLR2, TLR4, and TLR8. CLR signaling can "override" the response to a variety of otherwise proinflammatory TLR ligands such as LPS, instead inducing secretion of Th2-type or immunoregulatory cytokines, in a TLR-specific manner (124-127). In contrast, S. mansoni fucosylated glycolipids induce a pro-inflammatory response in DCs that is dependent on both DC-SIGN and TLR4 (128). The specific signaling interactions which contribute to this diverse response modulation are still being explored. Novel roles for CLRs interacting with schistosome glycoconjugates have been suggested by a glycoform of RNAse termed omega-1 (129), where uptake by MR may contribute to
RNAse internalization and impaired protein synthesis through degradation of both ribosomal and messenger RNA (130).

Thus, while much remains to be learned about parasite glycans and their bioactivities, the glycans of parasitic helminths have unique functions in innate immune responses and induce both CLR signaling as well as cross talk with TLR signaling in the human system. The molecular mechanisms of glycan-dependent innate immune responses are also linked to the adaptive immune responses, as discussed below. Understanding these responses could well lead to the development of novel therapeutic glycans that could be useful in treating human diseases associated with inflammation and autoimmunity.

\section{APPLICATIONS OF HELMINTH GLYCANS TO OTHER INFLAMMATORY AND INFECTIOUS DISEASES}

The immunomodulatory properties of helminth glycans are relevant not only to the outcomes of helminth infections, but may also be relevant to the outcomes of vaccinations, co-infections, and inflammatory disorders. Recently, many investigators have focused on understanding the effect that helminth immunomodulation has on responses to co-endemic infections such as Mycobacterium tuberculosis (MTB). Interestingly, it was found that N. brasiliensis, a mouse model for GI helminth infection that passes through the lungs, impairs ability to control MTB infection, and that this effect was mediated by IL-4 signaling of alternatively activated (M2 type) macrophages (131). Little work has been done on N. brasiliensis glycoconjugates, but they do have Tn antigen, and PC-containing glycoconjugates, which have several anti-inflammatory and other immunomodulatory actions $(42,132-135)$.

Helminth infections and their products have a phenomenal ability to ameliorate responses to a variety of inflammatory disorders (136). For example, in clinical studies of patients suffering from inflammatory bowel disease, treatment with the pig nematode T. suis, caused remission of Crohn's disease for more than half of the patients and improved the symptoms of Ulcerative Colitis for many patients $(137,138)$. Recently, two small clinical trials of multiple sclerosis (MS) patients - one comparing uninfected to those with naturally acquired $T$. suis infection, and the other using T. suis ova as treatment - suggested that T. suis may decrease unfavorable MRI changes, reduce exacerbations, and results in favorable immunological parameters such as elevated IL-4 and IL10 (139-141). The PC-containing helminth product ES-62 was recently shown to protect against airway inflammation in a mouse model of asthma (142).

Studies of helminth anti-inflammatory effects on some other disorders have been less favorable, such as the use of the hookworm N. americanus in Celiac Disease patients and T. suis for allergic rhinitis (143-145). The reasons for these failures are still unclear, but may include insufficient dose of worms, provocation of a mixed rather than purely immunoregulatory cytokine profile at safe doses, or a lack of effect at the level of symptoms even when the desired immunosuppressive responses are achieved in response to helminth treatment $(146,147)$. While controlled ingestion of therapeutic helminths has thus far been safe for adults, it can also cause significant gastrointestinal side effects (148). The anti-inflammatory molecules produced by the parasites, many of which, as mentioned above, are glycoconjugates, are not yet well 
defined. A better understanding of these molecules would allow us to channel the immunomodulatory properties of helminths into purer and more potent immunoregulatory therapies, with great potential for treating multiple chronic inflammatory diseases.

\section{ADAPTIVE IMMUNE RESPONSES TO HELMINTH-DERIVED GLYCANS}

Helminth infections present a dual challenge to immunologists: Firstly, we have an insufficient understanding of the immune effector mechanisms that successfully combat worms. Secondly, the study of adaptive immunity to eukaryotic pathogens has traditionally focused on protein, rather than glycan antigens. A large portion of the surface-exposed and secreted antigens of helminths consists of glycoconjugates $(17,149,150)$. Thus, crucial insights into immunological control of helminth infection lie at the intersection of these two fields, as we will now discuss.

\section{THE CHARACTER OF ADAPTIVE IMMUNITY TO HELMINTHS}

Due to the immunomodulatory effects of several glycoconjugates mentioned above, helminths usually elicit a Th2 response (Figure 1B). Non-endemic individuals newly exposed to S. mansoni can suffer from a more Th1-type acute disease known as Katayama fever, in which elevated levels of TNF, IL-1, and IL6 , accompany eosinophilia $(11,151)$, but people in endemic regions rarely suffer acute symptoms. Instead, they seem to be predisposed to developing a chronic, Th2-type response, the onset of which coincides with egg laying (11). This may stem from sensitization in utero or very early in life (152). The immune response to chronic helminth infection is dominated by a self-reinforcing Th2 feedback loop between cytokines IL-4, IL-5, IL-13, and prominent expansion of eosinophils and mast cells $(8,84)$. Initiation of this Th2 feedback loop has been a topic of intense investigation in the last few years, implicating mast cells, basophils, eosinophils, alternatively activated macrophages, and epithelial cells, just to name a few, as being required to initiate production of Th2 cytokines. Most recently, novel innate immune cell types such as the nuocyte have surfaced as the most likely Th2-initiating cells [reviewed in (153)]. Whatever the initiating Th2 cell type(s), it is likely that they receive important signals from helminth glycoconjugates, and little work has been done on the interactions of these molecules with such "unconventional" Th2-initiators.

During the chronic Th2 response, abundant antibodies of all subtypes are produced, especially IgE, IgG1, and $\operatorname{IgG} 4$ (22, 85, 154). In schistosomiasis, chronic pathology is primarily due to eosinophilic (type 2) granulomas, consisting of macrophages, $\mathrm{CD}^{+} \mathrm{T}$ cells, eosinophils, and collagen that surround eggs trapped in liver, intestinal, or bladder tissue, which are eventually converted to fibrotic scars $(11,155)$. Many other nematodes and cestodes also cause eosinophilic granulomas (84, 156-158).

The regulatory response is crucial in control of chronic helminth disease, for the well-being of both host and parasite (Figure 1B). Schistosomes, hookworms, and filarial nematodes all promote the development of $\mathrm{T}_{\text {regs }}$, and the production of regulatory cytokines like IL-10 and TGF- $\beta$ from multiple cell types, and IgG4, a non-complement fixing isotype. This type of response, collectively termed "modified Th2," serves to limit the immunopathology that would result from an uncontrolled
Th2 amplification-loop, and allows the host to remain relatively healthy for the long duration of helminth infection $(84,159,160)$. In concordance with this idea, schistosomiasis patients with chronic liver and spleen inflammation lack the IL-10 response to worm antigens, which is observed in chronic patients with low-level symptoms (85). AA-M $\Phi$ also aid in limiting worm-induced immunopathology. Alternative activation of macrophages is induced by Th2 cytokines like IL- 4 and IL-13 as well as directly by the products of several helminths, including $S$. mansoni, F. hepatica, filarial nematodes, and tapeworms (90, 150, 161-164). Though we have only just begun to define the sequelae of helminth glycoconjugate interactions with innate immune receptors, described above, it seems likely that this class of molecules plays a large role in dictating the character of the immune response to infection.

\section{CORRELATES OF PROTECTION FROM HELMINTH INFECTION}

Although the association of Th2-type immunity with helminths has been recognized for decades, we are still unraveling the effector mechanisms through which Th2 components control worm infections. Animal infections with gastrointestinal nematodes provide a model of an effective Th2-mediated response. Immunity to intestinal nematodes depends on Th2 cytokines (IL-4, IL-5, IL-9, and IL13) and is antagonized by Th1 cytokines. Mast cells and basophils are critical for expulsion of GI worms in some animal models, but are not always necessary $(165,166)$. Th2 cytokines have important protective effects directly on epithelial cells, including goblet cell hyperplasia, increased smooth muscle contractility, and secretion of molecules that directly target worms $(22,164,165)$.

Animal models of helminth infection have demonstrated that some immunological effector mechanisms are successful in combatting helminth infection. In the brown rat, which eliminates S. mansoni before patency, complement fixation, IgG2a and IgE levels, mast cell degranulation, and eosinophil-mediated antibodydependent cellular cytotoxicity (ADCC) have been cited in protection (167-172). In rhesus macaques, another protective model for schistosomiasis where adult worms become attenuated in the weeks after reaching patency, IgG-mediated complement killing of schistosomules, and neutralization of adult worms have been demonstrated (173-175). Other animal models have shown that eosinophils, monocytes/macrophages, and neutrophils can mediate in vitro ADCC of various helminth larvae including S. mansoni, F. hepatica, and S. stercoralis (176-178).

In human schistosomiasis cohorts, some adults acquire fewer infections and have lower worm burdens compared to children and more susceptible adults (179). Eosinophilia is a relatively wellestablished correlate of human schistosomiasis resistance (180, 181). Human eosinophils can kill schistosomula in vitro via IgG from infection antisera (182-184), however, there is no direct evidence that ADCC occurs during the course of human or animal infection, and eosinophilia can also be accounted for by the presence of type 2 granulomas (185). Mouse models of eosinophil knockout and eosinophil depletion have implicated a protective role for this cell type in some tissue-dwelling nematodes, but for many helminth models, eosinophils appear to play no role in protection [(186); and reviewed in (187)]. Rather than playing a direct role in the damage of worms, their importance may be to support 
other cells which have been shown to act directly on worms, such as basophils and alternatively activated macrophages [(188); and reviewed in (189)]. Thus, whether eosinophils contribute to protection in human helminth infections remains controversial.

High IgE levels (to heterogeneous schistosomula and adult antigens, as well as more specific antigens, such as Sm22) and high IgE/IgG4 ratios, are well-established correlates of human resistance to schistosomiasis, while IgG2, IgG4, and IgM are negatively correlated (190-194). IgA to the tegumental protein Sm28GST was also correlated with resistance in one study of human subjects (195). IgE is known to mediate mast cell degranulation, however, paradoxically, mastocytosis was found to correlate with susceptibility to reinfection in one occupationally exposed human schistosomiasis cohort (196). The negative correlation of IgM, IgG4, and IgG2 with human resistance has been attributed to their ability to block IgE and IgG-mediated effector mechanisms of parasite killing in vitro (191, 197-199). The factors that stimulate skewing toward production of either protective or blocking antibodies, sometimes to the same targets, are unknown.

An alternative hypothesis for the association of IgE with protection from schistosomiasis has been formulated based on the recent observation that $\mathrm{CD} 23^{+} \mathrm{B}$ cells are associated with resistance in a Kenyan cohort (200). B cells bind parasite-specific IgE through CD23, the low-affinity IgE receptor, and upon encountering parasite antigen, are activated by IgE crosslinking to endocytose the antigen. This mechanism could enable a large population of $B$ cells to present parasite epitopes to $T$ cells, which would in turn activate cognate parasite-specific B cells. The increasing amount of parasite-specific IgE could thus steadily increase the magnitude of the antibody response over the course of several infections, outweighing the immunosuppressive effects of some worm products (201). Such a robust IgE, IgG1, IgG3, and IgA antibody response would perhaps then be capable of destroying larvae and/or adult worms through a combination of the mechanisms discussed above.

$\mathrm{T}$ cell-mediated immunity may also play a role in the defense against helminth infection. Mice repeatedly vaccinated with irradiated S. mansoni cercaria develop a high level of protection which has been attributed to both Th1 and Th2 mechanisms, including complement activation, $\mathrm{CD}^{+}{ }^{+} \mathrm{T}$ cell cytotoxicity against schistosomula, and $\mathrm{T}$ cells and macrophages trapping schistosomula as they migrate through the lung (202-205). The protection of these mice is dependent on both antibodies and T cells (206-208). The role of Th1 responses in humans is still unclear. In some populations endemic for schistosomiasis and lymphatic filariasis, a mixed Th1/Th2 profile is associated with an effective immune response, whereas in hookworm infection, only Th2 appears to be correlated with resistance $(22,209)$. In some human populations, resistance to schistosome infection is correlated with increased production of IFN $\gamma$ by CD4 ${ }^{+}$T cells stimulated with recombinant Sm 14 protein and other antigens $(210,211)$. Polymorphisms in the IL-4 and IFN $\gamma$ genes have also been associated with resistance levels (212). Thus, while many possible in vitro and in vivo mechanisms against helminths have been described, it is yet unclear which, if any, of these is implemented by a successful human immune response, and which would be desirable in an anti-helminthic vaccine.

\section{THE ROLE OF GLYCANS IN ADAPTIVE IMMUNITY TO HELMINTHS}

Helminths produce an abundance of glycoconjugates that are a rich source of antigens for the immune system of their definitive hosts. For example, the S. mansoni cercarial glycocalyx, some of which is shed into the skin during penetration and some of which is retained on the parasite surface, is around $80 \%$ carbohydrate by weight $(17,149,150)$. In fact, the majority of the human and animal antibody response to schistosomes is directed to glycan antigens $(213,214)$. Anti-glycan antibodies $(\alpha$ GAbs $)$ are a common feature of helminth infections. It has been challenging to define their role in protection, in large part because, as described above, there is little consensus on the general mechanisms of immunity (anti-glycan or otherwise) that are protective against helminths, with different hosts likely employing different protective mechanisms. This section will highlight the importance of $\alpha \mathrm{GAbs}$ and address the continuing challenges to defining their role in helminth infection.

Helminths use specialized mechanisms to invade host organisms and establish a niche in their tissues for long-term survival or to enable passage of eggs out of the host. Helminth glycans are involved in the establishment of such niches, and antibodies to glycans can interfere with this process. The nematode T. spiralis, which causes trichinellosis, caps its multi-antennary $N$-glycans with the unique monosaccharide, tyvelose. Monoclonal antibodies to tyvelose are a major component of the natural protection conferred on suckling rat pups by infected dams and protect pups when passively transferred. In epithelial cell culture models, antibodies to tyvelose bind surface glycoproteins of the invading L1 larvae, inhibit migration into the cell layer and interfere with molting $(30,33,215,216)$. This could be how larvae are prevented from colonizing gastrointestinal epithelium in the protective models. While antibodies to tyvelose are protective in the rat model of $T$. spiralis infection, antibodies to PC moieties are not (217). Mucosal antibodies to a carbohydrate antigen of the gastrointestinal nematode Trichostrongylus colubriformis also prevent establishment of larvae in the sheep gut (218). In schistosomiasis, eggs must traverse the endothelium and intestinal wall in order to exit the host via stool. Using in vitro models of egg attachment to human umbilical vein endothelial cells, antibodies to E-selectin and Lex were shown to decrease adhesion (219). Whether the ability of $\alpha$ GAbs to interfere with host tissue interactions in the models is due to blockage of specific glycan-binding interaction or due to other neutralizing or physically damaging effects on the worms, is unclear. However, interference with invasion or adhesion through blocking surface glycans clearly represents an opportunity to induce protection and/or interfere with pathogenesis.

The antibody effector mechanisms most well known to damage or kill schistosomula in vitro are ADCC and complement activation, and $\alpha$ GAbs are capable of both. Pioneering work by the Capron group used a semi-permissive rat model to isolate an IgG2a called IPLSm1. The antibody killed schistosomula in vitro via eosinophil-mediated ADCC and passively transferred resistance to naïve rats (171). IPLSm1 targeted a $38-\mathrm{kDa}$ surface glycoprotein which was also recognized by infected monkey and human sera, and was cross reactive with Keyhole Limpet Hemocyanin (KLH) glycans $(220,221)$. Our present knowledge of KLH and 
schistosome cross-reactive glycans supports the hypothesis that IPLSm 1 targeted the FLDNF glycan $(49,50)$ (Table 1). The 38-kDa antigen was also used to develop an anti-idiotype vaccine, which conferred $50-80 \%$ protection to rats and induced antibodies that mediated ADCC (222). Mice also develop abundant antibodies to LDN-based glycans, including IgE, IgG1, and IgG3 (but not IgG2) to LDNF, indicative of a skewing toward Th2-type antibody effector mechanisms such as $\operatorname{ADCC}(223,224)$. A murine IgM to LDN isolated by our group mediates complement killing of schistosomula in vitro (122). The Harn group isolated three murine $\alpha$ GAbs, two of which, an IgM against the Lex antigen and an IgG2b against an unknown carbohydrate antigen, were protective and mediated in vitro complement killing, and an IgG3 that was not $(61,225)$.

Adaptive immunity to glycans may also be involved in aspects of helminth pathogenesis. LN- and LDN-coated beads induce schistosomiasis-like granulomas in murine livers. It is unclear whether this model works through adaptive or innate mechanisms, but fucosylated glycans known to bind C-type lectins did not induce granulomas $(226,227)$. The anti-Lex antibodies induced by schistosomes are cytolytic to human myeloid cell lines. These antibodies could potentially be responsible for mild neutropenia seen in infected humans, or for killing of schistosomula (63).

Antibodies generated by mammalian hosts to helminth glycans are not only abundant but highly specific. Schistosomes, for example, present the same glycan epitope in a variety of structural contexts, such as on $\mathrm{N}$ - and $\mathrm{O}$-glycans, or as single or multibranched glycans, as diagrammed in Table 1. The structural presentation of such epitopes as Lex and LDNF can vary among schistosome life stages, localization, and sexes (48, 228, 229). Data from our lab and others have demonstrated that monoclonal antibodies and sera from infected hosts can discriminate against very similar epitopes, such as the monomeric, biantennary $N$-glycan, and multimeric forms of the Lex or LDNF trisaccharide epitopes $(60,228)$. Given that some of these structural variants are somewhat similar to mammalian glycans, this high level of specificity could be crucial to developing an effective parasite-specific antibody response. Anti-schistosomal monoclonal antibodies with well-defined glycan specificity can be used to isolate parasite glycoconjugates and potentially identify novel vaccine targets including both glycan and protein epitopes (60). We and others are developing the Glycomics tools that will help us to better define the specificity of the $\alpha$ GAbs against helminths (230-232).

Whether human resistance to helminth infection is mediated by $\alpha$ GAbs is a fascinating but complex question, which has only been addressed in a handful of studies examining correlative evidence. S. mansoni-exposed humans and non-human primates make antibodies to glycan epitopes with fucosylation patterns unique to schistosomes such as FLDN and $\operatorname{LDN}-D F(233,234)$. One group observed that a Kenyan population showed decreases in IgG1 to FLDN and LDN-DF, and increases in IgM to LDNDF and LDNF, over the course of 2 years after migrating from a non-endemic to schistosomiasis-endemic area; the same associations were seen with increasing age in the schistosomiasis-endemic resident population (234). Levels of IgE to worm glycolipids prepraziquantel treatment were inversely correlated with egg burden 2 years after treatment in another population (235). Using shotgun glycan microarrays made from the intra-mammalian stages of schistosomes, other investigators have found that S. mansoniinfected adults make IgG and IgM to several fucosylated glycan epitopes, and that children have modestly higher titers than adults to most glycans $(230,236)$. Collectively, these studies are difficult to interpret, due to the challenges of identifying human populations that truly show variable resistance and susceptibility (mechanisms of which likely differ among populations), the difficulty of obtaining glycan preparations that are both pure and accurately mimic the mode of presentation by the parasite, and the differential significance of antibody isotypes and sub-isotypes in human resistance. Further studies are needed to strengthen these correlations and more directly examine the role of $\alpha \mathrm{GAbs}$ in protection from schistosomiasis and other human helminth infections.

Other reports have indicated that antibodies to glycans can be non-protective or even block the development of resistance to helminths. Heligmosomoides polygyrus, a well-studied mouse model of gastrointestinal nematode infection, elicits a nonprotective immunodominant response to an O-linked glycan on VAL antigens (237). Following isolation of a protective IgG2a against S. mansoni $38-\mathrm{kDa}$ antigen mentioned above, a second antibody, an IgG2c that targeted the same glycan, was isolated from infected rats. The IgG2c blocked the protective effect of the IgG2a in vitro and in vivo, which may be why a response to this epitope was correlated with infection in humans but not with resistance (197). It had earlier been hypothesized, based on results from a complex series of experiments on chronically infected and radiation-attenuated cercariae vaccinated mouse sera, that levels of antibody to parasite surface antigens is not simply correlated with protection. Protection may instead depend on a particular balance of blocking and protective antibodies, possibly against the same antigens (238). Clearly such counteractive effects of antibodies to glycan antigens should be explored in more detail.

The lesson of all of these studies is that helminth glycans, like protein epitopes, can induce both protective and non-protective antibodies. Rather than viewing glycans as a class of targets and asking, "is their role protective or subversive?" we should continue to identify particular anti-glycan specificities and isotypes that can afford protection, design experiments to directly test their role, and develop technologies to better understand which structural presentations and innate cues are required to incite production of protective versus non-protective antibodies.

\section{APPLICATIONS OF HELMINTH GLYCANS TO DIAGNOSIS AND VACCINATION}

It has long been known that helminths synthesize unique glycan structures, which are targeted by the adaptive immune response in natural infection; however, this rich collection of antigens has yet to translate into molecular targets for diagnostics and vaccines. This section will emphasize research on how control of helminth infection can be improved by exploiting glycans as novel diagnostic and vaccine targets.

Treatment of helminth infections currently relies on chemotherapeutics such as albendazole and praziquantel $(6,239)$. Prevalence in some areas is so high that mass drug administration (MDA) has been implemented for school-age children. Chemotherapy significantly decreases worm burden and morbidity but is not always curative, and its effectiveness varies depending 
on the worm life stage. Single-dose cure rates range from 15 to $72 \%$ in various helminth infections (239). However, the effectiveness of MDA in controlling transmission and reducing morbidity is difficult to determine, because traditional diagnostic methods are laborious and insufficient to detect low-level infection or track variations in worm burden $(240,241)$. The "gold standard" for diagnosis of helminth infection continues to be microscopic examination of stool or urine samples for eggs. However, eggs are not consistently shed into feces and urine. Despite improvements in the sensitivity and ease-of-use of these tests, stool samples are still difficult to obtain in the field, often yield false negatives due to temporal variation in egg-laying, and differentiation of the type of helminth eggs in stool requires skilled laboratory technicians (239-242).

Commercial ELISA-based detection kits are available for diagnosis of some parasites including malaria (Plasmodium species), cryptosporidiosis, and giardia in stool, urine, or serum samples. For helminths causing schistosomiasis, filariasis, and trichinellosis, antibody-based tests are available from commercial sources or by special request from the CDC but are not widely used in endemic areas $(9,243)$. Antibody tests are generally sensitive, but they suffer several drawbacks, such as inability to differentiate between active (acute or chronic) and past infections, cross-reactivity among multiple helminth species, and difficulty of performance in the field $(242,243)$.

Recent studies have uncovered a new set of potential diagnostic antigens, found in serum and urine, for schistosomiasis and other helminths. Carbohydrate-based antigens and $\alpha$ GAbs are promising tools given that they are chemically stable, specific to particular helminth species, vary with stage of infection, and are expressed both on worm surfaces and in secreted products. Several glycan-based detection methods are now in the pipeline for schistosomiasis $(244,245)$. A point-of-care urine dipstick test for the schistosome excreted circulating cathodic antigen (CCA) (Table 1), whose antigenicity is due to Lex repeats, is now commercially available $(245,246)$. It is easier to perform in the field and has higher sensitivity than a single Kato-Katz smear, and it can detect prepatent infections in very young children $(245,247,248)$. Additionally, a test for the other well-studied circulating schistosome glycan antigen, circulating anodic antigen (CAA), which is excreted by adult worms into urine and serum, has recently been adapted for field use with promising results. The test is highly sensitive and can detect just a few worm pairs (249). These and other novel diagnostic tests are ready for rigorous comparison in the field and are likely to change the face of schistosomiasis diagnostics in upcoming years. Another epitope, apparently unique to schistosomes, is DF-LDN-DF, which forms the epitope for the monoclonal antibody $114-4 \mathrm{D} 12$. This antibody can be used to isolate free urinary glycans for detection by mass spectrometry, and to identify the DF-LDN-DF on egg glycoproteins from the blood or urine via ELISA $(243,250,251)$.

Molecular detection of trichinellosis identifies antibodies to the TSL- 1 glycoprotein, of which $\beta$-tyvelose is the immunodominant epitope. Synthetic tyvelose outperformed worm ES antigens in detection of these antibodies via ELISA $(9,72,252)$. The cestode Echinococcus multilocularis, which causes rare but serious infection in humans, is detected by ultrasonography and antibodies to the Em2 glycoprotein $(9,253)$. Recently, it was shown that the immunodominant Em2 epitope is a unique O-linked glycan capping structure, Galp $\alpha 1-4 \mathrm{Gal}$, and that antibodies to this structure were highly sensitive and specific for detection of infected patient sera via ELISA $(254,255)$. The same group has also identified a novel glycoprotein for detection of E. multilocularis infection in dogs, which may be an important source of human acquisition (253).

Modern glycan microarray technology is also being used to identify new glycan candidates for diagnosis of helminths. Studies have shown that LDNF, which is more easily produced in the lab than tyvelose, is also a sensitive indicator of T. spiralis infection (256). Similarly, results from glycan microarray analyses have shown that the sheep nematode $H$. contortus possesses Gal $\alpha 1$ 3 GalNAc, which is antigenic and uncommon among nematodes and trematodes (257). These new microarray technologies have the promising ability to screen a single sample for antibodies to multiple glycans from different helminth species, many of which are co-endemic, in a microscale assay. Thus, glycan arrays have enormous potential to define the diagnostic antigens of the future.

Development of resistance to anti-helminthics, especially in the face of MDA, has long been of concern. Reduced susceptibility to praziquantel has been reported in some human schistosomiasisendemic areas, and it is possible to generate resistant schistosomes in the lab (258). Only one new anti-helminthic, tribendimidine, has become available in the last 30 years $(259,260)$. However, its mechanism is similar to two existing anti-helminthics, and little research is taking place to discover novel mechanisms and drug targets $(6,261)$. Donations of such drugs are currently meeting only 5 and $49 \%$ of the global need for schistosomiasis and hookworms, respectively, and these drugs do not interrupt the chain of transmission, owing to variable efficacy rates, animal reservoirs, and frequent re-infections in children $(3,5,7,242)$. Clearly, vaccines that expedite the development of immunity are a much-needed intervention in control of helminths.

Animal models of vaccine-induced immunity to helminths have used attenuated parasites and worm lysates or other worm products. Due to the difficulty of maintaining a complex life cycle in large scale, and the danger associated with manufacturing this type of vaccine, it is unlikely to be a practical solution. Modern vaccine development for parasitic helminths has focused on recombinant proteins but not on glycoproteins, which represent the major targeted antigens of infection. In the mid-1990s, six S. mansoni proteins, studied in various labs, were chosen by the WHO to undergo independent laboratory testing. None of these reached the required $40 \%$ effectiveness required to move past animal testing (262). Two candidates have more recently reached the clinical phase. Bilhvax (Sh28-GST) has progressed through phase I, II, and III trials, however, there has been a more than 10 -year delay in publishing the results (263). Another candidate schistosomiasis vaccine, Sm14, may enter clinical trials this year, and at least two more candidates are progressing through the pre-clinical pipeline (264). The N. americanus protein ASP2 was clinically tested for prevention of hookworm, but recipients of the vaccine developed hives $(265,266)$. Currently two more hookworm candidates, GST1 and APR1, are being developed and clinical testing for GST1 should start soon $(8,265,267)$. These studies 
highlight the difficulty of identifying effective targets and inducing the proper character of immune response for helminth vaccines. Modern methods of producing recombinant glycoproteins may allow future targeting of specific glycoprotein antigens for vaccine studies.

Localization of target proteins may be one of the problems with early vaccine candidates for schistosomiasis. Several of the protein candidates were later identified in the worm tegument, but only one was found in apical membrane preparations $(14,268)$. A newer strategy is to use proteomic studies to identify protein candidates which are exposed on the worms' surface, accessible to immune effectors, and vital for worm functions such as membrane assembly and blood feeding $(8,269,270)$. One of these studies used biotinylation reagents to label accessible adult $S$. mansoni tegument proteins. Only a small subset of proteins was identified, suggesting that many surface proteins are shielded from immune attack by the glycan and lipid-rich membranocalyx $(8,270)$. In light of the difficulties faced in developing recombinant protein candidates as schistosome vaccines, we suggest taking advantage of the rich collection of non-protein antigens surrounding vulnerable stages of the worms.

Given the rapid turnover of helminth surface antigens, variation in their expression among life stages, a successful vaccine may need to target more than one epitope. Glycan epitopes offer the advantage of being densely distributed on numerous glycoconjugates on the parasite surface, and expressed throughout multiple life stages. The schistosome is a well-characterized demonstration of this observation. Our group has shown that LDN and LDNF are expressed on the surface of S. mansoni cercariae, schistosomula, and adult worms as well as in SEA (122), and that LDNF is expressed on all three major schistosome species (223). Other fucosylated variants which are not shared by mammalian hosts, such as LDN-DF and FLDNF, have been localized to eggs, cercariae, adult gut, and tegument, and appear on numerous distinct glycoproteins and glycolipids as detected by ELISA, Western blotting, and immunofluorescence of whole parasites and parasite sections $(20,271)$. An additional advantage is that because glycan structure is not linearly encoded in the genome, selective pressure is less likely to result in the escape of glycosylation mutants than is the case for proteins.

Vaccination experiments have also demonstrated that eukaryotic glycoconjugates are viable vaccine targets. Vaccination of lambs with alhydrogel-adjuvant excreted/secreted products of the nematode $H$. contortus conferred a high level of protection which was correlated with IgG antibodies to LDNF and Gal $\alpha 1-3$ GalNAc $(257,272)$. Other studies that used natively purified activationassociated secreted proteins (ASPs) from the cattle nematode $O$. ostertagi also afforded protection, and showed that the recombinantly produced ASPs from $E$. coli were unable to induce protection or any antibodies to native ASPs (273). Hybrid-type $N$-glycan structures were characterized on the native protein and, while antisera were not directly reactive with the glycan structures, it was hypothesized that they were necessary for proper folding of the native antigen. Another approach taken was to explore an anti-idiotype vaccine, which was found to be protective in rats and to generate immunity to a $38-\mathrm{kDa}$ glycoprotein antigen mentioned above (222). A vaccine against a $P$. falciparum glycosylphosphatidylinositol (GPI) induced IgG that was able to neutralize parasite pathogenesis in vitro (274).

Further studies are needed to better define the glycan antigen structures of helminths, to develop novel methods of producing and presenting eukaryotic glycans in an immunogenic fashion, and to discover the glycosyltransferases necessary to generate the worm glycan structures that are foreign to mammals. The central role of glycans in adaptive immunity to helminths and these early studies into their protective capacity indicates that, with further innovation, glycan-based diagnostics and vaccines may be an important intervention in the control of helminth infection.

\section{GLYCAN INTERACTIONS WITH INTERMEDIATE HOSTS}

As previously stated, schistosomes synthesize a complex array of glycan structures on both membrane and secreted glycoconjugates. Many of these glycans have been found to be potent antigens in vertebrate hosts, but their roles in snail infections are poorly understood (275-277). Emerging evidence suggests that schistosome glycoconjugates play a pivotal role in both cellular and humoral immune interactions between their molluscan intermediate hosts and the infecting larval stages (277-279).

There appears to be a role for fucosylated carbohydrate epitopes expressed by larval and adult schistosomes in parasite evasion in intermediate and definitive hosts $(275,280,281)$. During invasion of the snail body, the miracidia penetrate the epithelium allowing for direct interaction of the snail tissues with the miracidial glycocalyx. The carbohydrate epitopes present on the surface of the miracidium during this time may be of prime importance during the invasion process. Recently, it was shown that B. glabrata synthesizes a broad battery of $N$-glycans on multiple glycoproteins comprising at least two carbohydrate determinants that cross-react with glycoconjugates from S. mansoni eggs (282).

It is well known that $S$. mansoni glycan expression is developmentally and stage-specifically regulated, but until recently, the glycan epitopes expressed in miracidia and sporocysts were largely unknown. Using a mass spectrometry approach for glycomic profiling, Hokke et al. found evidence for expression of multifucosylated, LDN-terminating di- and tri-antennary structures, as well as the presence of the truncated trimannosyl and corexylosylated/core- $\alpha-1,3$-fucosylated $N$-glycans in miracidia (283). Lehr et al. demonstrated the surface expression of FLDN, FLDNF, LDNF, and LDN-DF in miracidia and the presence of these, as well as non-fucosylated LDN, and Lex glycans in secondary sporocysts (275, 282, 283). Alpha-1,3-fucosylated LDN structures (FLDN, FLDNF, LDNF) are prominently expressed on the larval surface and amongst glycoproteins released during larval transformation and early sporocyst development. This stage-specific expression implies a role for these glycans in snail-schistosome interactions. Also, sharing of specific glycans FLDN and trimannosyl $N$-glycans with $B$. glabrata suggests an evolutionary convergence of carbohydrate expression between schistosomes and their snail host (275).

Larval glycans and/or their associated glycoconjugates might also be serving as PAMPs that interact with lectin-like PRRs (284). PRRs, such as Toll receptors, C-type lectins, galectins, nucleic acid-sensing receptors, and the intracellular nucleotide-binding oligomerization domain (NOD)-like receptors (NLRs) occur both 
extracellularly and intracellularly, with the galectins notably found in both the cytoplasm and extracellularly (285). In terms of glycoconjugates in helminth infections and their interactions with all types of PRRs, little is known, and the most well-studied interactions involve C-type lectins and galectins. There is also evidence that glycans may be important in the intermediate hosts' innate immunity and PRR recognition and may involve novel PRRs. During their development in the molluscan intermediate host, S. mansoni sporocysts release excretory/secretory glycoproteins that bind to lectin PRRs on the surface of the snail host hemocytes and are believed to modulate the ability of the hemocytes to interact with the developing larvae (279). The binding of glycoconjugates to $B$. glabrata hemocyte lectins can trigger the generation of parasitekilling reactive oxygen species, thereby mediating innate immune responses to invading miracidia $(10,275,277,280,281,284)$.

Glycans may also be the targets of humoral immune responses mounted by the molluscan hosts against larval infection. $B$. glabrata snails respond to infection by secreting humoral factors into their hemolymph that bind and precipitate larval excretory/secretory antigens. These factors contain $\mathrm{N}$ - and C-terminal domains with similarities to immunoglobulin super-family proteins and fibrinogen, respectively, and are called fibrinogen-related proteins (FREPs) $(277,284,286)$. To counteract FREPs, developing primary sporocysts envelope themselves in a glycan-rich environment comprised mainly of glycoproteins and other glycoconjugates referred to as larval transformation products (LTPs) (284, 287). LTP glycoconjugates released during transformation are able to alter patterns of shared glycan epitopes by either binding and blocking, or by exposing them. This is a possible mechanism by which molecules released from early developing larvae may impact initial immune interactions at the host-parasite interface and shows the potent immune modulating effects of LTPs $(284,288)$.

\section{CONCLUSION AND FUTURE PERSPECTIVES}

Molecular insights into the innate and adaptive immune responses to glycoconjugates of parasitic helminths are providing new directions for developing diagnostics, therapeutics, and potential vaccines toward these organisms. Developing evidence indicates that parasitic helminths utilize a wide variety of glycosylated molecules to successfully infect their vertebrate and often invertebrate hosts. The parasite glycans are characterized by their complex structures

\section{REFERENCES}

1. First WHO Report on Neglected Tropical Diseases: Working to Overcome the Global Impact of Neglected Tropical Diseases. Geneva: WHO (2010). Available from: http://www.who.int/neglected_ diseases/2010report/en/

2. The Global Burden of Disease: 2004 Update. Geneva: WHO (2008). Available from: http://www.who. int/healthinfo/global_burden_ disease/2004_report_update/en/

3. Hotez PJ, Fenwick A, Savioli L, Molyneux DH. Rescuing the bottom billion through control of neglected tropical diseases. Lancet (2009) 373: 1570-5. doi:10.1016/S01406736(09)60233-6

4. Bethony J, Brooker S, Albonico $\mathrm{M}$, Geiger SM, Loukas A, Diemert D, et al. Soil-transmitted helminth infections: ascariasis, trichuriasis, and hookworm. Lancet (2006) 367:1521-32. doi:10.1016/S01406736(06)68653-4

5. King $\mathrm{CH}$, Sturrock RF, Kariuki HC, Hamburger J. Transmission control for schistosomiasis - why it matters now. Trends Parasitol (2006) 22:575-82. doi:10.1016/j. pt.2006.09.006

that are often multifucosylated and rich in unusual monosaccharides and modifications, making them strong targets for adaptive immune responses. Such unusual glycans also demonstrate strong recognition and signaling by DCs and M $\Phi$ s, through lectins, TLRs and CLRs, and other antigen-processing cells that serve to limit inflammation and promote parasite survival. The cross talk that occurs from these glycan-dependent signals is important in initiation of the adaptive immune response, but could also contribute to the overall polarization of immunosuppressive responses to the parasite infections. Many glycoconjugates of parasites are potent immune modulators which have the potential to be channeled into effective immunoregulatory therapies with potential for treating multiple chronic inflammatory diseases, such as MS or Crohn's disease. While glycans are targets in natural infections, much remains to be learned about the expression and functions of parasite-derived glycans, and their potential role in resistance to infection. While some glycans are useful in diagnostics and monitoring, none of the specific glycans of these parasites has yet been translated into molecular targets for vaccines.

Some of the key questions that need to be addressed in helminth glyco-immunology are: what is the full range of unique helminth glycans and how is their expression on glycoconjugates regulated? What is the full repertoire of glycan-binding proteins or receptors on host cells that function to respond to helminth glycans? Which glycans are responsible for the immunosuppressive effects of helminth products? What signaling pathways mediate the complex cross-talk among CLRs and other PRRs? What are the vaccine design considerations for utilizing parasite glycan antigens, which are structurally distinct from repeating bacterial polysaccharide antigens? Which anti-glycan antibody isotypes/arms of effector immunity are protective in helminth infection? Can glycans be used as diagnostics to differentiate among co-endemic helminth infections and active versus cured infections? And could glycan-based interactions with intermediate hosts be exploited for transmission control? Given the growing realization that the parasite glycome is active in pathogenesis and resistance, it will be exciting to see the coming results from future research in this key area of biomedical importance worldwide.

\section{ACKNOWLEDGMENTS}

The authors acknowledge funding to Richard D. Cummings from the NIGMS of the NIH under award number GM098791.

6. Harhay MO, Horton J, Olliaro PL. Epidemiology and control of human gastrointestinal parasites in children. Expert Rev Anti Infect Ther (2010) 8:219-34. doi:10.1586/eri. 09.119

7. Hotez PJ, Engels D, Fenwick A, Savioli L. Africa is desperate for praziquantel. Lancet (2010) 376:496-8. doi:10.1016/S01406736(10)60879-3

8. Hotez PJ, Bethony JM, Diemert DJ, Pearson M, Loukas A. Developing vaccines to combat hookworm infection and intestinal schistosomiasis. Nat
Rev Microbiol (2010) 8:814-26. doi:10.1038/nrmicro2438

9. DPDx. Laboratory Identification of Parasites of Public Health Concern. Centers for Disease Control and Prevention (2009). Available from: http://www.dpd.cdc.gov/dpdx/ Default.htm [accessed November 8, 2011].

10. Bayne CJ. Successful parasitism of vector snail Biomphalaria glabrata by the human blood fluke (trematode) Schistosoma mansoni: a 2009 assessment. Mol Biochem Parasitol (2009) 165: 8-18. doi:10.1016/j.molbiopara. 2009.01.005 
11. Pearce EJ, MacDonald AS. The immunobiology of schistosomiasis. Nat Rev Immunol (2002) 2:499-511. doi:10.1038/nri843

12. Da'dara AA, Li YS, Xiong T, Zhou J, Williams GM, McManus DP, et al. DNA-based vaccines protect against zoonotic schistosomiasis in water buffalo. Vaccine (2008) 26:3617-25. doi:10.1016/j.vaccine. 2008.04.080

13. Page AP, Johnstone IL. The cuticle. In: The C. elegans Research Community, WormBook, editor. WormBook (2007). doi:10.1895/ wormbook.1.138.1. Available from http://www.wormbook.org

14. Braschi S, Borges WC, Wilson RA. Proteomic analysis of the schistosome tegument and its surface membranes. Mem Inst Oswaldo Cruz (2006) 101:205-12. doi:10. 1590/S0074-02762006000900032

15. Dalton JP, Lewis SA, Aronstein WS, Strand M. Schistosoma mansoni: immunogenic glycoproteins of the cercarial glycocalyx. Exp Parasitol (1987) 63:215-26. doi:10. 1016/0014-4894(87)90164-0

16. Abou-Zakham AA, Romia SA, ElNaggar HS, El-Khouly ES. Ultra structure study of schistosomula recovered after cercarial penetration of isolated skin. J Egypt Soc Parasitol (1990) 20:579-87.

17. Samuelson JC, Caulfield JP. The cercarial glycocalyx of Schistosoma mansoni. J Cell Biol (1985) 100:1423-34. doi:10.1083/jcb.100. 5.1423

18. Kusel JR, Al-Adhami BH, Doenhoff MJ. The schistosome in the mammalian host: understanding the mechanisms of adaptation. Parasitology (2007) 134: 1477-526. doi:10.1017/ S0031182007002971

19. Simpson AJ, Payares G, Walker T, Knight M, Smithers SR. The modulation of expression of polypeptide surface antigens on developing schistosomula of Schistosoma mansoni. J Immunol (1984) 133:2725-30.

20. Robijn MLM, Wuhrer M, Kornelis D, Deelder AM, Geyer R, Hokke $\mathrm{CH}$. Mapping fucosylated epitopes on glycoproteins and glycolipids of Schistosoma mansoni cercariae, adult worms and eggs. Parasitology (2005) 130:67-77. doi:10. 1017/S0031182004006390

21. Pearson MS, Pickering DA, Tribolet L, Cooper L, Mulvenna J, Oliveira LM, et al. Neutralizing antibodies to the hookworm hemoglobinase Na-APR-1: implications for a multivalent vaccine against hookworm infection and schistosomiasis. J Infect Dis (2010) 201:1561-9. doi:10.1086/651953

22. McSorley HJ, Loukas A. The immunology of human hookworm infections. Parasite Immunol (2010) 32:549-59.

23. Cummings RD, Nyame AK. Schistosome glycoconjugates. Biochim Biophys Acta (1999) 1455:36374. doi:10.1016/S0925-4439(99) 00063-0

24. Nyame K, Smith DF, Damian RT, Cummings RD. Complextype asparagine-linked oligosaccharides in glycoproteins synthesized by Schistosoma mansoni adult males contain terminal betalinked N-acetylgalactosamine. J Biol Chem (1989) 264:3235-43.

25. Makaaru CK, Damian RT, Smith DF, Cummings RD. The human blood fluke Schistosoma mansoni synthesizes a novel type of glycosphingolipid. J Biol Chem (1992) 267:2251-7.

26. Kang S, Cummings RD, McCall JW. Characterization of the $\mathrm{N}$-linked oligosaccharides in glycoproteins synthesized by microfilariae of Dirofilaria immitis. J Parasitol (1993) 79:815-28. doi:10.2307/3283717

27. Srivatsan J, Smith DF, Cummings RD. Schistosoma mansoni synthesizes novel biantennary Asn-linked oligosaccharides containing terminal beta-linked $\mathrm{N}$-acetylgalactosamine. Glycobiology (1992) 2:445-52. doi:10.1093/ glycob/2.5.445

28. Neeleman AP, van der Knaap WP, van den Eijnden DH. Identification and characterization of a UDP-GalNAc:GlcNAcB-R B1-4$\mathrm{N}$-acetylgalactosaminyltransferase from cercariae of the schistosome Trichobilharzia ocellata. Catalysis of a key step in the synthesis of N,N'-diacetyllactosediamino (lacdiNAc)-type glycans. Glycobiology (1994) 4:641-51.

29. van den Eijnden DH, Neeleman AP, van der Knap WPW, Bakker $\mathrm{H}$, Agterberg M, van Die I. Novel glycosylation routes for glycoproteins: the lacdiNAc pathway. Biochem Soc Trans (1995) 23. 175-9.

30. Ellis LA, Reason AJ, Morris HR, Dell A, Iglesias R, Ubeira FM, et al. Glycans as targets for monoclonal antibodies that protect rats against Trichinella spiralis. Glycobiology (1994) 4:585-92. doi:10. 1093/glycob/4.5.585

31. Reason AJ, Ellis LA, Appleton JA, Wisnewski N, Grieve RB, McNeil
$\mathrm{M}$, et al. Novel tyvelose-containing tri- and tetra-antennary $\mathrm{N}$-glycans in the immunodominant antigens of the intracellular parasite Trichinella spiralis. Glycobiology (1994) 4:593-603. doi:10. 1093/glycob/4.5.593

32. Ellis LA, McVay CS, Probert MA, Zhang J, Bundle DR, Appleton JA. Terminal beta-linked tyvelose creates unique epitopes in Trichinella spiralis glycan antigens. Glycobiology (1997) 7:383-90. doi:10.1093/ glycob/7.3.383

33. McVay CS, Bracken P, Gagliardo LF, Appleton J. Antibodies to tyvelose exhibit multiple modes of interference with the epithelial niche of Trichinella spiralis. Infect Immun (2000) 68:1912-8. doi:10.1128/IAI.68.4.1912-1918. 2000

34. Moller LN, Petersen E, Gamble HR, Kapel CM. Comparison of two antigens for demonstration of Trichinella spp. antibodies in blood and muscle fluid of foxes, pigs and wild boars. Vet Parasitol (2005) 132:81-4. doi:10.1016/ j.vetpar.2005.05.032

35. Bruschi F, Moretti A, Wassom D, Piergili Fioretti D. The use of a synthetic antigen for the serological diagnosis of human trichinellosis. Parasite (2001) 8: S141-3.

36. Shepherd JC, McManus DP. Specific and cross-reactive antigens of Echinococcus granulosus hydatid cyst fluid. Mol Biochem Parasitol (1987) 25:143-54. doi:10.1016/0166-6851(87) 90003-X

37. Paschinger K, GonzalezSapienza GG, Wilson IBH. Mass spectrometric analysis of the immunodominant glycan epitope of Echinococcus granulosus antigen Ag5. Int J Parasitol (2012) 42:279-85. doi:10.1016/j.ijpara.2012.01.002

38. Cipollo JF, Awad AM, Costello CE, Hirschberg CB. N-glycans of Caenorhabditis elegans are specific to developmental stages. J Biol Chem (2005) 280:26063-72. doi: 10.1074/jbc.M503828200

39. Grabitzki J, Ahrend M, Schachter H, Geyer R, Lochnit G. The PCome of Caenorhabditis elegans as a prototypic model system for parasitic nematodes: identification of phosphorylcholine-substituted proteins. Mol Biochem Parasitol (2008) 161:101-11. doi:10.1016/j. molbiopara.2008.06.014

40. Lochnit G, Nispel S, Dennis RD, Geyer R. Structural analysis and immunohistochemical localization of two acidic glycosphingolipids from the porcine, parasitic nematode, Ascaris suum. Glycobiology (1998) 8:891-9. doi:10.1093/ glycob/8.9.891

41. Fletcher TC, White A, Baldo BA. Isolation of a phosphorylcholinecontaining component from the turbot tapeworm, Bothriocephalus scorpii (Müller), and its reaction with C-reactive protein. Parasite Immunol (1980) 2:237-48. doi:10. 1111/j.1365-3024.1980.tb00056.x

42. van Die I, Cummings RD. Glycomics in unraveling glycandriven immune responses by parasitic helminths. In: Cummings RD, Pierce JM, editors. Handbook of Glycomics. San Diego, CA: Elsevier Academic Press (2009). p. 367-96.

43. Khoo KH, Maizels RM, Page AP, Taylor GW, Rendell NB, Dell A. Characterization of nematode glycoproteins: the major O-glycans of Toxocara excretory-secretory antigens are $\mathrm{O}$-methylated trisaccharides. Glycobiology (1991) 1: 163-71. doi:10.1093/glycob/1.2. 163

44. Koizumi A, Yamano K, Tsuchiya T, Schweizer F, Kiuchi F, Hada N. Synthesis, antigenicity against human sera and structure-activity relationships of carbohydrate moieties from Toxocara larvae and their analogues. Molecules (2012) 17:9023-42. doi:10.3390/molecules17089023

45. Khoo KH, Sarda S, Xu X, Caulfield JP, McNeil MR, Homans SW, et al. A unique multifucosylated 3GalNAc beta $1->4$ GlcNAc beta 1->3Gal alpha 1- motif constitutes the repeating unit of the complex O-glycans derived from the cercarial glycocalyx of Schistosoma mansoni. J Biol Chem (1995) 270:17114-23. doi: 10.1074/jbc.270.29.17114

46. Wuhrer M, Kantelhardt SR, Dennis RD, Doenhoff MJ, Lochnit G, Geyer R. Characterization of glycosphingolipids from Schistosoma mansoni eggs carrying Fuc(a1-3)GalNAc-, GalNAc(B14) $[\operatorname{Fuc}(\mathrm{al}-3)] \mathrm{GlcNAc}-$ and Gal(B1-4)[Fuc(a1-3)]GlcNAc(Lewis $\mathrm{X}$ ) terminal structures. Eur J Biochem (2002) 269:481-93. doi:10.1046/j.0014-2956.2001 02673.x

47. Wuhrer M, Koeleman CAM, Hokke CH. Mass spectrometry of proton adducts of fucosylated $\mathrm{N}$-glycans: fucose transfer between antennae gives rise to misleading fragments. Rapid Commun Mass 
Spectrom (2006) 20(11):1747-54. doi:10.1002/rcm.2509

48. Wuhrer M, Koeleman CAM, Deelder AM, Hokke CH. Repeats of LacdiNAc and fucosylated LacdiNAc on N-glycans of the human parasite Schistosoma mansoni. FEBS J (2006) 273: 347-61. doi:10.1111/j.1742-4658. 2005.05068.x

49. Kantelhardt SR, Wuhrer M, Dennis RD, Doenhoff MJ, Bickle Q, Geyer R. Fuc(alpha 1->3)GalNAc: the major antigenic motif of Schistosoma mansoni glycolipids implicated in infection sera and keyhole-limpet haemocyanin cross-reactivity. Biochem J (2002) 366:217-23.

50. Geyer H, Wuhrer M, Resemann A, Geyer R. Identification and characterization of keyhole limpet hemocyanin N-glycans mediating cross-reactivity with Schistosoma mansoni. J Biol Chem (2005) 280:40731-48. doi:10.1074/jbc.M505985200

51. Frank S, van Die I, Geyer R. Structural characterization of Schistosoma mansoni adult worm glycosphingolipids reveals pronounced differences with those of cercariae. Glycobiology (2012) 22:676-95. doi:10.1093/glycob/cws004

52. Jang-Lee J, Curwen RS, Ashton PD, Tissot B, Mathieson W, Panico $M$, et al. Glycomics analysis of Schistosoma mansoni egg and cercarial secretions. Mol Cell Proteomics (2007) 6:1485-99. doi:10.1074/mcp.M700004MCP200

53. van Diepen A, van der Velden NSJ, Smit CH, Meevissen MHJ, Hokke CH. Parasite glycans and antibodymediated immune responses in schistosoma infection. Parasitology (2012) 139:1219-30. doi:10.1017/ S0031182012000273

54. Yan S, Bleuler-Martinez S, Plaza DF, Künzler M, Aebi M, Joachim A, et al. Galactosylated fucose epitopes in nematodes: increased expression in a Caenorhabditis mutant associated with altered lectin sensitivity and occurrence in parasitic species. $J$ Biol Chem (2012) 287:28276-90. doi:10.1074/jbc.M112.353128

55. Hanneman AJ, Rosa JC, Ashline D, Reinhold VN. Isomer and glycomer complexities of core GlcNAcs in Caenorhabditis elegans. Glycobiology (2006) 16:874-90. doi:10.1093/glycob/cwl011

56. Paschinger K, Gutternigg $\mathrm{M}$, Rendic D, Wilson IB. The
$\mathrm{N}$-glycosylation pattern of Caenorhabditis elegans. Carbohydr Res (2008) 343:2041-9. doi:10.1016/j.carres.2007.12.018

57. Takeuchi T, Nishiyama K, Sugiura K, Takahashi M, Yamada A, Kobayashi S, et al. Caenorhabditis elegans galectins LEC- 6 and LEC-1 recognize a chemically synthesized Galbeta1-4Fuc disaccharide unit which is present in protostomia glycoconjugates. Glycobiology (2009) 19:1503-10. doi:10. 1093/glycob/cwp125

58. Takeuchi T, Tamura M, Nishiyama $\mathrm{K}$, Iwaki J, Hirabayashi J, Takahashi $\mathrm{H}$, et al. Mammalian galectins bind Galactoseß1-4Fucose disaccharide, a unique structural component of protostomial N-type glycoproteins. Biochem Biophys Res Commun (2013) 436(3):509-13. doi:10.1016/j.bbrc.2013.05.135

59. Srivatsan J, Smith DF, Cummings RD. The human blood fluke Schistosoma mansoni synthesizes glycoproteins containing the Lewis $X$ antigen. J Biol Chem (1992) 267:20196-203.

60. Mandalasi M, Dorabawila N, Smith DF, Heimburg-Molinaro J, Nyame AK, Cummings RD. Development and characterization of a specific IgG monoclonal antibody toward the Lewis $\mathrm{x}$ antigen using splenocytes of Schistosoma mansoni infected mice. Glycobiology (2013) 23:877-92. doi:10. 1093/glycob/cwt025

61. Ko AI, Dräger UC, Harn DA. A Schistosoma mansoni epitope recognized by a protective monoclonal antibody is identical to the stage-specific embryonic antigen 1. Proc Natl Acad Sci U S A (1990) 87:4159-63. doi:10.1073/pnas.87. 11.4159

62. Haslam SM, Coles GC, Morris HR, Dell A. Structural characterization of the N-glycans of Dictyocaulus viviparus: discovery of the Lewis $(\mathrm{x})$ structure in a nematode. Glycobiology (2000) 10:2239. doi:10.1093/glycob/10.2.223

63. Nyame AK, Pilcher JB, Tsang VCW, Cummings RD. Schistosoma mansoni infection in humans and primates induces cytolytic antibodies to surface $\mathrm{Le}(\mathrm{x})$ determinants on myeloid cells. Exp Parasitol (1996) 82:191-200. doi:10.1006/ expr.1996.0024

64. Bergwerff AA, van Dam GJ, Rotmans JP, Deelder AM, Kamerling JP, Vliegenthart JF. The immunologically reactive part of immunopurified circulating anodic antigen from Schistosoma mansoni is a threonine-linked polysaccharide consisting of $\left(\begin{array}{ll}-> & 6\end{array}\right)$-(beta-D-GlcpA-(1 --> 3))-beta-D-GalpNAc-(1 --> repeating units. $J$ Biol Chem (1994) 269:31510-7.

65. Deelder AM, Kornelis D, Van Marck EAE, Eveleigh PC, Van Egmond JG. Schistosoma mansoni: characterization of two circulating polysaccharide antigens and the immunological response to these antigens in mouse, hamster, and human infections. Exp Parasitol (1980) 50:16-32. doi:10.1016/ 0014-4894(80)90004-1

66. Lochnit G, Dennis RD, Zahringer U, Geyer R. Structural analysis of neutral glycosphingolipids from Ascaris suum adults (Nematoda:Ascaridida). $\quad$ Glycoconj J (1997) 14:389-99. doi:10.1023/A:1018530914067

67. Damian RT. Molecular mimicry: antigen sharing by parasite and host and its consequences. Am Nat (1964) 98:129-49. doi:10. 1086/282313

68. Damian RT. Molecular mimicry revisited. Parasitol Today (Regul Ed) (1987) 3:263-6. doi:10.1016/ 0169-4758(87)90102-5

69. Talabnin K, Aoki K, Saichua P, Wongkham S, Kaewkes S, Boons G-J, et al. Stage-specific expression and antigenicity of glycoprotein glycans isolated from the human liver fluke, Opisthorchis viverrini. Int J Parasitol (2013) 43:37-50. doi:10.1016/j.ijpara.2012.10.013

70. Wuhrer M, Grimm C, Dennis RD, Idris MA, Geyer R. The parasitic trematode Fasciola hepatica exhibits mammalian-type glycolipids as well as Gal(beta16) Gal-terminating glycolipids that account for cestode serological cross-reactivity. Glycobiology (2004) 14:115-26. doi:10.1093/ glycob/cwh021

71. Yamano K, Goto A, NakamuraUchiyama F, Nawa $\mathrm{Y}$, Hada N, Takeda T. GalB1-6Gal, antigenic epitope which accounts for serological cross-reaction in diagnosis of Echinococcus multilocularis infection. Parasite Immunol (2009) 31:481-7. doi:10.1111/j. 1365-3024.2009.01129.x

72. Bolás-Fernandez F, Corral Bezara LD. TSL-1 antigens of Trichinella: an overview of their potential role in parasite invasion, survival and serodiagnosis of trichinellosis. Res Vet Sci (2006) 81:297-303. doi:10. 1016/j.rvsc.2006.01.002

73. Kariuki TM, Farah IO, Wilson RA, Coulson PS. Antibodies elicited by the secretions from schistosome cercariae and eggs are predominantly against glycan epitopes. Parasite Immunol (2008) 30:55462. doi:10.1111/j.1365-3024.2008. 01054.x

74. Eberl M, Langermans JA, Vervenne RA, Nyame AK, Cummings RD, Thomas AW, et al. Antibodies to glycans dominate the host response to schistosome larvae and eggs: is their role protective or subversive? J Infect Dis (2001) 183:1238-47. doi:10.1086/319691

75. Yuki N, Susuki K, Koga M, Nishimoto $Y$, Odaka M, Hirata $K$, et al. Carbohydrate mimicry between human ganglioside GM1 and Campylobacter jejuni lipooligosaccharide causes Guillain-Barre syndrome. Proc Natl Acad Sci U S A (2004) 101:11404-9. doi:10.1073/ pnas.0402391101

76. Yu RK, Ariga T, Usuki S, Kaida K. Pathological roles of ganglioside mimicry in GuillainBarre syndrome and related neuropathies. Adv Exp Med Biol (2011) 705:349-65. doi:10.1007/ 978-1-4419-7877-6_17

77. van Die I, Cummings RD. Glycan gimmickry by parasitic helminths: a strategy for modulating the host immune response? Glycobiology (2010) 20:2-12. doi:10.1093/ glycob/cwp140

78. Pohleven J, Obermajer N, Sabotic J, Anzlovar S, Sepcic K, Kos J, et al. Purification, characterization and cloning of a ricin B-like lectin from mushroom Clitocybe nebularis with antiproliferative activity against human leukemic T cells. Biochim Biophys Acta (2009) 1790: 173-81. doi:10.1016/j.bbagen. 2008.11.006

79. Pohleven J, Renko M, Magister Š, Smith DF, Künzler M, Štrukelj B, et al. Bivalent carbohydrate binding is required for biological activity of Clitocybe nebularis lectin (CNL), the $\mathrm{N}, \mathrm{N}^{\prime}$-diacetyllactosediamine (GalNAcB1-4GlcNAc, LacdiNAc)specific lectin from basidiomycete C. nebularis. J Biol Chem (2012) 287:10602-12. doi:10.1074/jbc.M111.317263

80. Butschi A, Titz A, Walti MA, Olieric $\mathrm{V}$, Paschinger K, Nobauer K, et al. Caenorhabditis elegans N-glycan core beta-galactoside confers sensitivity towards nematotoxic fungal galectin CGL2. PLoS Pathog (2010) 6:e1000717. doi:10.1371/ journal.ppat.1000717

81. Kent ML, Bishop-Stewart JK, Matthews JL, Spitsbergen JM. 
Pseudocapillaria tomentosa, a nematode pathogen, and associated neoplasms of zebrafish (Danio rerio) kept in research colonies. Comp Med (2002) 52:354-8.

82. Kent ML, Harper C, Wolf JC. Documented and potential research impacts of subclinical diseases in zebrafish. ILAR J (2012) 53:126-34. doi:10.1093/ilar.53.2. 126

83. Balla KM, Lugo-Villarino G, Spitsbergen JM, Stachura DL, Hu Y, Bañuelos K, et al. Eosinophils in the zebrafish: prospective isolation, characterization, and eosinophilia induction by helminth determinants. Blood (2010) 116:3944-54. doi:10.1182/ blood-2010-03-267419

84. Allen JE, Maizels RM. Diversity and dialogue in immunity to helminths. Nat Rev Immunol (2011) 11:375-88. doi:10.1038/ nri2992

85. Caldas IR, Campi-Azevedo AC, Oliveira LFA, Silveira AMS, Oliveira RC, Gazzinelli G. Human schistosomiasis mansoni: immune responses during acute and chronic phases of the infection. Acta Trop (2008) 108:109-17. doi:10.1016/j.actatropica.2008.05. 027

86. Kapsenberg ML. Dendritic-cell control of pathogen-driven T-cell polarization. Nat Rev Immunol (2003) 3:984-93. doi:10.1038/nri1246

87. Mosser DM, Edwards JP. Exploring the full spectrum of macrophage activation. Nat Rev Immunol (2008) 8:958-69. doi:10.1038/nri2448

88. Maizels RM, Balic A, GomezEscobar N, Nair M, Taylor MD, Allen JE. Helminth parasites - masters of regulation. Immunol Rev (2004) 201:89-116. doi:10.1111/j.0105-2896.2004. 00191.x

89. Maizels RM, Yazdanbakhsh M. $\mathrm{T}$-cell regulation in helminth parasite infections: implications for inflammatory diseases. Chem Immunol Allergy (2008) 94:11223. doi:10.1159/000154944

90. Reyes JL, Terrazas LI. The divergent roles of alternatively activated macrophages in helminthic infections. Parasite Immunol (2007) 29:609-19. doi:10.1111/j.13653024.2007.00973.x

91. Tundup S, Srivastava L, Harn DA. Polarization of host immune responses by helminth-expressed glycans. Ann N Y Acad Sci
(2012) 1253:E1-13. doi:10.1111/j. 1749-6632.2012.06618.x

92. Geijtenbeek TBH, van Vliet SJ, Engering A, 't Hart BA, van Kooyk Y. Self- and nonself-recognition by C-type lectins on dendritic cells. Annu Rev Immunol (2004) 22:33-54. doi:10.1146/annurev. immunol.22.012703.104558

93. Medzhitov R. Toll-like receptors and innate immunity. Nat Rev Immunol (2001) 78:1-56.

94. Banchereau J, Steinman RM. Dendritic cells and the control of immunity. Nature (1998) 392:245-52. doi:10.1038/32588

95. van den Berg LM, Gringhuis SI, Geijtenbeek TB. An evolutionary perspective on C-type lectins in infection and immunity. Ann N Y Acad Sci (2012) 1253:14958. doi:10.1111/j.1749-6632.2011. 06392.x

96. Mascanfroni ID, Cerliani JP, Dergan-Dylon S, Croci DO, Ilarregui JM, Rabinovich GA. Endogenous lectins shape the function of dendritic cells and tailor adaptive immunity: mechanisms and biomedical applications. Int Immunopharmacol (2011) 11:833-41. doi:10.1016/j.intimp.2011.01.021

97. Quintin J, Saeed S, Martens JHA, Giamarellos-Bourboulis EJ, Ifrim DC, Logie C, et al. Candida albicans infection affords protection against reinfection via functional reprogramming of monocytes. Cell Host Microbe (2012) 12:223-32. doi:10.1016/j.chom.2012.06.006

98. van Vliet SJ, García-Vallejo JJ, van Kooyk Y. Dendritic cells and C-type lectin receptors: coupling innate to adaptive immune responses. Immunol Cell Biol (2008) 86:580-7. doi:10.1038/icb. 2008.55

99. van Liempt E, van Vliet SJ, Engering A, García Vallejo JJ, Bank CMC, Sanchez-Hernandez $\mathrm{M}$, et al. Schistosoma mansoni soluble egg antigens are internalized by human dendritic cells through multiple C-type lectins and suppress TLR-induced dendritic cell activation. Mol Immunol (2007) 44:2605-15. doi:10.1016/j. molimm.2006.12.012

100. van den Berg TK, Honing $H$, Franke N, van Remoortere A, Schiphorst WE, Liu F, et al. LacdiNAc-glycans constitute a parasite pattern for galectin3-mediated immune recognition. J Immunol (2004) 173(3): 1902-7.
101. Grzych J, Pearce E, Cheever A, Caulada ZA, Caspar P, Lewis F, et al. Egg deposition is the major stimulus for the production of Th2 cytokines in murine schistosomiasis mansoni. J Immunol (1991) 146:1322-7.

102. Velupillai P, Harn DA Oligosaccharide-specific induction of interleukin 10 production by $\mathrm{B} 220+$ cells from schistosome-infected mice: a mechanism for regulation of CD4+ T-cell subsets. Proc Natl Acad Sci U S A (1994) 91:18-22. doi:10.1073/pnas.91.1.18

103. Okano M, Satoskar AR, Nishizaki $\mathrm{K}$, Abe M, Harn DA Jr. Induction of Th2 responses and IgE is largely due to carbohydrates functioning as adjuvants on Schistosoma mansoni egg antigens. J Immunol (1999) 163:6712-7.

104. Thomas PG, Harn DA Jr. Immune biasing by helminth glycans. Cell Microbiol (2004) 6:13-22. doi:10. 1046/j.1462-5822.2003.00337.x

105. Kuijk LM, Klaver EJ, Kooij G, van der Pol SMA, Heijnen P, Bruijns SCM, et al. Soluble helminth products suppress clinical signs in murine experimental autoimmune encephalomyelitis and differentially modulate human dendritic cell activation. Mol Immunol (2012) 51:210-8. doi:10.1016/j. molimm.2012.03.020

106. Klaver EJ, Kuijk LM, Laan LC, Kringel H, van Vliet SJ, Bouma G, et al. Trichuris suis-induced modulation of human dendritic cell function is glycan-mediated. Int $J$ Parasitol (2013) 43:191-200. doi: 10.1016/j.ijpara.2012.10.021

107. Tawill S, Le Goff L, Ali F, Blaxter M, Allen JE. Both free-living and parasitic nematodes induce a characteristic Th2 response that is dependent on the presence of intact glycans. Infect Immun (2004) 72:398-407. doi:10.1128/ IAI.72.1.398-407.2004

108. Terrazas CA, Gómez-García L, Terrazas LI. Impaired proinflammatory cytokine production and increased Th2-biasing ability of dendritic cells exposed to Taenia excreted/secreted antigens: a critical role for carbohydrates but not for STAT6 signaling. Int J Parasitol (2010) 40:1051-62. doi:10.1016/j.ijpara

109. Gómez-García L, Rivera-Montoya I, Rodríguez-Sosa M, Terrazas LI. Carbohydrate components of Taenia crassiceps metacestodes display Th2-adjuvant and antiinflammatory properties when co-injected with bystander antigen. Parasitol Res (2006) 99:440-8. doi:10.1007/s00436-006-0159-2

110. Okano M, Satoskar AR, Nishizaki

K, Harn DA Jr. Lacto-Nfucopentaose III found on Schistosoma mansoni egg antigens functions as adjuvant for proteins by inducing Th2-type response. $J$ Immunol (2001) 167:442-50.

111. Thomas PG, Carter MR, Atochina O, Da'dara AA, Piskorska D, McGuire E, et al. Maturation of dendritic cell 2 phenotype by a helminth glycan uses a Toll-like receptor 4-dependent mechanism. J Immunol (2003) 171:5837-41.

112. Atochina O, Harn D. LNFPIII/LeX-stimulated macrophages activate natural killer cells via CD40-CD40L interaction. Clin Diagn Lab Immunol (2005) 12:1041-9.

113. Thomas PG, Carter MR, Da'dara AA, DeSimone TM, Harn DA. A helminth glycan induces APC maturation via alternative NF-kappa B activation independent of I kappa B alpha degradation. J Immunol (2005) 175:2082-90.

114. Faveeuw C, Mallevaey T, Paschinger K, Wilson IBH, Fontaine J, Mollicone $\mathrm{R}$, et al. Schistosome N-glycans containing core alpha 3-fucose and core beta 2-xylose epitopes are strong inducers of Th2 responses in mice. Eur J Immunol (2003) 33:1271-81. doi:10.1002/eji.200323717

115. Faveeuw C, Angeli V, Fontaine J, Maliszewski C, Capron A, van Kaer $\mathrm{L}$, et al. Antigen presentation by CD1d contributes to the amplification of Th2 responses to Schistosoma mansoni glycoconjugates in mice. J Immunol (2002) 169:90612.

116. van der Kleij D, van Remoortere A, Schuitemaker JH, Kapsenberg ML, Deelder AM, Tielens AG, et al. Triggering of innate immune responses by schistosome egg glycolipids and their carbohydrate epitope GalNAc betal-4(Fuc alpha 1-2Fuc alpha 1-3)GlcNAc. J Infect Dis (2002) 185:531-9. doi:10.1086/338574

117. van Die I, van Vliet SJ, Nyame AK, Cummings RD, Bank CMC, Appelmelk B, et al. The dendritic cell-specific C-type lectin DCSIGN is a receptor for Schistosoma mansoni egg antigens and recognizes the glycan antigen Lewis $\mathrm{x}$. Glycobiology (2003) 13:471-8. doi: $10.1093 /$ glycob/cwg052

118. van Liempt E, Bank CMC, Mehta P, Garciá-Vallejo JJ, Kawar ZS, Geyer R, et al. Specificity of 
DC-SIGN for mannose- and fucose-containing glycans. FEBS Lett (2006) 580:6123-31. doi:10. 1016/j.febslet.2006.10.009

119. van Vliet SJ, van Liempt E, Saeland E, Aarnoudse CA, Appelmelk B, Irimura $\mathrm{T}$, et al. Carbohydrate profiling reveals a distinctive role for the C-type lectin MGL in the recognition of helminth parasites and tumor antigens by dendritic cells. Int Immunol (2005) 17:661-9. doi:10.1093/intimm/ dxh246

120. Meevissen MHJ, Driessen NN, Smits HH, Versteegh R, van Vliet SJ, van Kooyk Y, et al. Specific glycan elements determine differential binding of individual egg glycoproteins of the human parasite Schistosoma mansoni by host Ctype lectin receptors. Int J Parasitol (2012) 42:269-77. doi:10.1016/j. ijpara.2012.01.004

121. van Vliet SJ, Saeland E, van Kooyk Y. Sweet preferences of MGL: carbohydrate specificity and function. Trends Immunol (2008) 29:83-90. doi:10.1016/j.it.2007.10.010

122. Nyame AK, Lewis FA, Doughty BL, Correa-Oliveira R, Cummings RD. Immunity to schistosomiasis: glycans are potential antigenic targets for immune intervention. Exp Parasitol (2003) 104:1-13. doi:10. 1016/S0014-4894(03)00110-3

123. Sancho D, Reis e Sousa C. Signaling by myeloid C-type lectin receptors in immunity and homeostasis. Annu Rev Immunol (2012) 30:491-529. doi:10.1146/annurevimmunol-031210-101352

124. Geijtenbeek TBH, Gringhuis SI. Signalling through Ctype lectin receptors: shaping immune responses. Nat Rev Immunol (2009) 9:465-79. doi:10.1038/nri2569

125. Meevissen MHJ, Yazdanbakhsh M, Hokke CH. Schistosoma mansoni egg glycoproteins and C-type lectins of host immune cells: molecular partners that shape immune responses. Exp Parasitol (2012) 132:14-21. doi:10.1016/j.exppara. 2011.05.005

126. van Die I, Cummings RD. Glycans modulate immune responses in helminth infections and allergy. Chem Immunol Allergy (2006) 90:91-112.

127. Kuijk LM, van Die I. Worms to the rescue: can worm glycans protect from autoimmune diseases? IUBMB Life (2010) 62:303-12. doi: 10.1002/iub.304

128. van Stijn CMW, Meyer S, van den Broek M, Bruijns SCM, van
Kooyk Y, Geyer R, et al. Schistosoma mansoni worm glycolipids induce an inflammatory phenotype in human dendritic cells by cooperation of TLR4 and DC-SIGN. Mol Immunol (2010) 47:1544-52. doi: 10.1016/j.molimm.2010.01.014

129. Meevissen MH, Wuhrer M, Doenhoff MJ, Schramm G, Haas H, Deelder AM, et al. Structural characterization of glycans on omega1, a major Schistosoma mansoni egg glycoprotein that drives Th2 responses. J Proteome Res (2010) 9:2630-42. doi:10.1021/ pr100081c

130. Everts B, Hussaarts L, Driessen NN, Meevissen $\mathrm{MH}$, Schramm G, van der Ham AJ, et al. Schistosomederived omega-1 drives Th2 polarization by suppressing protein synthesis following internalization by the mannose receptor. $J$ Exp Med (2012) 209:1753-67, S1. doi:10. 1084/jem.20111381

131. Potian JA, Rafi W, Bhatt K, McBride A, Gause WC, Salgame P. Preexisting helminth infection induces inhibition of innate pulmonary antituberculosis defense by engaging the IL-4 receptor pathway. J Exp Med (2011) 208:1863-74. doi:10.1084/jem.20091473

132. Lochnit G, Dennis RD, Ulmer AJ, Geyer R. Structural elucidation and monokine-inducing activity of two biologically active zwitterionic glycosphingolipids derived from the porcine parasitic nematode Ascaris suum. J Biol Chem (1998) 273:466-74. doi:10.1074/ jbc. 273.1 .466

133. Deehan MR, Goodridge HS, Blair D, Lochnit G, Dennis RD, Geyer R, et al. Immunomodulatory properties of Ascaris suum glycosphingolipids - phosphorylcholine and non-phosphorylcholinedependent effects. Parasite Immunol (2002) 24:463-9. doi:10. 1046/j.1365-3024.2002.00489.x

134. van Riet E, Wuhrer M, Wahyuni S, Retra K, Deelder AM, Tielens AGM, et al. Antibody responses to Ascaris-derived proteins and glycolipids: the role of phosphorylcholine. Parasite Immunol (2006) 28:363-71. doi:10.1111/j. 1365-3024.2006.00844.x

135. Péry P, Luffau G, Charley J, Petit A, Rouze P, Bernard S. Phosphorylcholine antigens from Nippostrongylus brasiliensis. II. Isolation and partial characterization of phosphorylcholine antigens from adult worm. Ann Immunol (Paris) (1979) 130:889-900.
136. Rook GAW. Review series on helminths, immune modulation and the hygiene hypothesis: the broader implications of the hygiene hypothesis. Immunology (2009) 126:3-11. doi:10.1111/j. 1365-2567.2008.03007.x

137. Summers RW, Elliott DE, Urban JF, Thompson RA, Weinstock JV. Trichuris suis therapy for active ulcerative colitis: a randomized controlled trial. Gastroenterology (2005) 128:825-32. doi:10.1053/j. gastro.2005.01.005

138. Summers RW, Elliott DE, Urban JF, Thompson R, Weinstock JV. Trichuris suis therapy in Crohn's disease. Gut (2005) 54:87-90. doi: 10.1136/gut.2004.041749

139. Fleming JO, Isaak A, Lee JE, Luzzio CC, Carrithers MD, Cook TD, et al. Probiotic helminth administration in relapsing-remitting multiple sclerosis: a phase 1 study. Mult Scler (2011) 17:743-54. doi: 10.1177/1352458511398054

140. Correale J, Farez M. Association between parasite infection and immune responses in multiple sclerosis. Ann Neurol (2007) 61:97-108. doi:10.1002/ana.21067

141. Benzel F, Erdur H, Kohler S, Frentsch M, Thiel A, Harms L, et al. Immune monitoring of Trichuris suis egg therapy in multiple sclerosis patients. J Helminthol (2012) 86:339-47. doi:10.1017/ S0022149X11000460

142. Rzepecka J, Siebeke I, Coltherd JC, Kean DE, Steiger CN, AlRiyami L, et al. The helminth product, ES-62, protects against airway inflammation by resetting the Th cell phenotype. Int J Parasitol (2013) 43:211-23. doi:10. 1016/j.ijpara.2012.12.001

143. Daveson AJ, Jones DM, Gaze S, McSorley H, Clouston A, Pascoe A, et al. Effect of hookworm infection on wheat challenge in celiac disease - a randomised doubleblinded placebo controlled trial. PLoS ONE (2011) 6:e17366. doi:10.1371/journal.pone. 0017366

144. Hamid F, Wiria AE, Wammes LJ, Kaisar MM, Lell B, Ariawan I, et al. A longitudinal study of allergy and intestinal helminth infections in semi urban and rural areas of Flores, Indonesia (ImmunoSPIN Study). BMC Infect Dis (2011) 11:83. doi:10.1186/1471-2334-1183

145. Croft AM, Bager P, Kumar S. Helminth therapy (worms) for allergic rhinitis. Cochrane Database Syst Rev (2012) 4:CD009238.
doi:10.1002/14651858.CD009238. pub2

146. Bourke CD, Mutapi F, Nausch N, Photiou DMF, Poulsen LK, Kristensen B, et al. Trichuris suis ova therapy for allergic rhinitis does not affect allergenspecific cytokine responses despite a parasite-specific cytokine response. Clin Exp Allergy (2012) 42:1582-95. doi:10.1111/j.13652222.2012.04063.x

147. McSorley HJ, Gaze S, Daveson J, Jones D, Anderson RP, Clouston A, et al. Suppression of inflammatory immune responses in celiac disease by experimental hookworm infection. PLoS ONE (2011) 6:e24092. doi:10. 1371/journal.pone.0024092

148. Bager P, Kapel C, Roepstorff A, Thamsborg S, Arnved J, Rønborg S, et al. Symptoms after ingestion of pig whipworm Trichuris suis eggs in a randomized placebo-controlled double-blind clinical trial. PLoS ONE (2011) 6:e22346. doi:10.1371/journal. pone. 0022346

149. Caulfield JP, Cianci CML, McDiarmid SS, Suyemitsu T, Schmid K. Ultrastructure, carbohydrate, and amino acid analysis of two preparations of the cercarial glycocalyx of Schistosoma mansoni. J Parasitol (1987) 73:514-22. doi:10. 2307/3282129

150. Gómez-García L, López-Marín LM, Saavedra R, Reyes JL, Rodríguez-Sosa M, Terrazas LI. Intact glycans from cestode antigens are involved in innate activation of myeloid suppressor cells. Parasite Immunol (2005) 27:395-405. doi:10.1111/j.13653024.2005.00790.x

151. de Jesus AR, Silva A, Santana LB, Magalhães A, de Jesus AA, de Almeida RP, et al. Clinical and immunologic evaluation of 31 patients with acute schistosomiasis mansoni. J Infect Dis (2002) 185:98-105. doi:10.1086/ 324668

152. King CL, Malhotra I, Mungai P, Wamachi A, Kioko J, Ouma $\mathrm{JH}$, et al. B cell sensitization to helminthic infection develops in utero in humans. J Immunol (1998) 160:3578-84.

153. Neill DR, McKenzie ANJ. Nuocytes and beyond: new insights into helminth expulsion. Trends Parasitol (2011) 27:214-21. doi:10. 1016/j.pt.2011.01.001

154. Wright V, Bickle Q. Immune responses following experimental human hookworm infection. Clin 
Exp Immunol (2005) 142:398403. doi:10.1111/j.1365-2249. 2005.02945.x

155. Bogitsh BJ. Schistosoma mansoni: cytochemistry of eosinophils in egg-caused early hepatic granulomas of mice. Exp Parasitol (1971) 29:493-500. doi:10.1016/ 0014-4894(71)90058-0

156. Musso C, Castelo JS, Tsanaclis AMC, Pereira FEL. Prevalence of Toxocara-induced liver granulomas, detected by immunohistochemistry, in a series of autopsies at a Children's Reference Hospital in Vitoria, ES, Brazil. Virchows Arch (2007) 450:411-7. doi: 10.1007/s00428-007-0388-5

157. Lobo-Sanahuja F, LoboSanahuja JF. Clinical abdominal angiostrongylosis. A study of 116 children with intestinal eosinophilic granuloma caused by Angiostrongylus costaricensis. Am J Trop Med Hyg (1980) 29(4):538-44.

158. Sirikulchayanonta V, Chongchitnant N. Gnathostomiasis, a possible etiologic agent of eosinophilic granuloma of the gastrointestinal tract. Am J Trop Med Hyg (1979) 28:42-4.

159. Everts B, Smits HH, Hokke CH, Yazdanbakhsh M. Helminths and dendritic cells: sensing and regulating via pattern recognition receptors, Th2 and Treg responses. Eur IImmunol (2010) 40:1525-37. doi:10.1002/eji.200940109

160. Hoerauf A, Satoguina J, Saeftel $\mathrm{M}$, Specht S. Immunomodulation by filarial nematodes. Parasite Immunol (2005) 27:417-29. doi:10.1111/j.1365-3024.2005. 00792.x

161. Donnelly S, Stack CM, O’Neill SM, Sayed AA, Williams DL, Dalton JP. Helminth 2-Cys peroxiredoxin drives Th2 responses through a mechanism involving alternatively activated macrophages. FASEB $J$ (2008) 22:4022-32. doi:10.1096/fj. 08-106278

162. Rodríguez-Sosa M, Satoskar AR, Calderón R, Gomez-Garcia L, Saavedra R, Bojalil R, et al. Chronic helminth infection induces alternatively activated macrophages expressing high levels of CCR5 with low interleukin-12 production and Th2-biasing ability. Infect Immun (2002) 70:3656-64. doi:10. 1128/IAI.70.7.3656-3664.2002

163. Nair MG, Cochrane DW, Allen JE. Macrophages in chronic type 2 inflammation have a novel phenotype characterized by the abundant expression of $\mathrm{Yml}$ and
Fizzl that can be partly replicated in vitro. Immunol Lett (2003) 85:173-80. doi:10.1016/ S0165-2478(02)00225-0

164. Perrigoue JG, Marshall FA, Artis D. On the hunt for helminths: innate immune cells in the recognition and response to helminth parasites. Cell Microbiol (2008) 10(9):1757-64. doi:10.1111/j. 1462-5822.2008.01174.x

165. Artis D. New weapons in the war on worms: identification of putative mechanisms of immunemediated expulsion of gastrointestinal nematodes. Int J Parasitol (2006) 36:723-33. doi:10.1016/j. ijpara.2006.02.011

166. Nel HJ, Hams E, Saunders SP, Mangan NE, Smith P, Atzberger A, et al. Impaired basophil induction leads to an age-dependent innate defect in type 2 immunity during helminth infection in mice. $J$ Immunol (2011) 186:4631-9. doi: 10.4049/jimmunol.1002995

167. Ford MJ, Dissous C, Pierce RJ, Taylor MG, Bickle QD, Capron A. The isotypes of antibody responsible for the "late" passive transfer of immunity in rats vaccinated with highly irradiated cercariae. Parasitology (1987) 94(Pt 3):509-22. doi:10.1017/S0031182000055852

168. Cutts L, Wilson RA. Elimination of a primary schistosome infection from rats coincides with elevated $\operatorname{IgE}$ titres and mast cell degranulation. Parasite Immunol (1997) 19:91-102. doi:10.1046/j. 1365-3024.1997.d01-184.x

169. Miller HR, Newlands GF, McKellar A, Inglis L, Coulson PS, Wilson RA. Hepatic recruitment of mast cells occurs in rats but not mice infected with Schistosoma mansoni. Parasite Immunol (1994) 16:14555. doi:10.1111/j.1365-3024.1994. tb00334.x

170. Vignali DA, Bickle QD, Taylor MG, Tennent G, Pepys MB. Comparison of the role of complement in immunity to Schistosoma mansoni in rats and mice. Immunology (1988) 63:55-61

171. Grzych J, Capron M, Bazin $\mathrm{H}$, Capron A. In vitro and in vivo effector function of rat IgG2a monoclonal anti-S. mansoni antibodies. J Immunol (1982) 129:2739-43.

172. Ramalho-Pinto FJ, McLaren DJ, Smithers SR. Complementmediated killing of schistosomula of Schistosoma mansoni by rat eosinophils in vitro. $J$ Exp Med (1978) 147:147-56. doi:10.1084/jem.147.1.147
173. Wilson RA, Langermans JAM, van Dam GJ, Vervenne RA, Hall SL, Borges WC, et al. Elimination of Schistosoma mansoni adult worms by rhesus macaques: basis for a therapeutic vaccine? PLoS Negl Trop Dis (2008) 2:e290. doi:10. 1371/journal.pntd.0000290

174. Smithers SR, Terry RJ. Naturally acquired resistance to experimental infections of Schistosoma mansoni in the rhesus monkey (Macaca mulatta). Parasitology (1965) 55:701-10.

175. Clegg JA, Smithers SR. The effects of immune rhesus monkey serum on schistosomula of Schistosoma mansoni during cultivation in vitro. Int $\mathrm{J}$ Parasito (1972) 2:79-98. doi:10.1016/00207519(72)90036-7

176. Piedrafita D, Parsons JC, Sandeman RM, Wood PR, Estuningsih SE, Partoutomo S, et al. Antibody-dependent cellmediated cytotoxicity to newly excysted juvenile Fasciola hepatica in vitro is mediated by reactive nitrogen intermediates. Parasite Immunol (2001) 23:473-82. doi:10.1046/j.1365-3024.2001. 00404.x

177. Ligas JA, Kerepesi LA, Galioto AM, Lustigman S, Nolan TJ, Schad GA, et al. Specificity and mechanism of immunoglobulin $\mathrm{M}$ ( $\operatorname{Ig} M)$ - and IgG-dependent protective immunity to larval Strongyloides stercoralis in mice. Infect Immun (2003) 71:6835-43. doi:10.1128/ IAI.71.12.6835-6843.2003

178. Butterworth AE, Sturrock RF, Houba V, Taylor R. Schistosoma mansoni in baboons: antibodydependent cell-mediated damage to 51Cr-labelled schistosomula. Clin Exp Immunol (1976) 25:95102.

179. Karanja DMS, Hightower AW, Colley DG, Mwinzi PNM, Galil $\mathrm{K}$, Andove J, et al. Resistance to reinfection with Schistosoma mansoni in occupationally exposed adults and effect of HIV-1 coinfection on susceptibility to schistosomiasis: a longitudinal study. Lancet (2002) 360:592-6. doi:10.1016/S0140-6736(02) 09781-7

180. Hagan P, Blumenthal UJ, Chaudri M, Greenwood BM, Hayes RJ, Hodgson J, et al. Resistance to reinfection with Schistosoma haematobium in Gambian children: analysis of their immune responses. Trans $R$ Soc Trop Med Hyg (1987) 81:938-46. doi:10. 1016/0035-9203(87)90359-2
181. Ganley-Leal LM, Mwinzi PN, Catherine B, Andove J, Hightower AW, Diana $\mathrm{M}$, et al. Correlation between eosinophils and protection against reinfection with Schistosoma mansoni and the effect of human immunodeficiency virus type 1 coinfection in humans. Infect Immun (2006) 74:2169-217. doi:10.1128/IAI.74. 4.2169-2176.2006

182. Butterworth AE, Sturrock RF, Houba V. Antibody-dependent cell-mediated damage to schistosomula in vitro. Nature (1974) 252:503-5. doi:10.1038/252503a0

183. Butterworth AE, Remold HG, Houba V, David R, Franks D, David $\mathrm{PH}$, et al. Antibody-dependent eosinophil-mediated damage to 51 Cr-labeled schistosomula of Schistosoma mansoni: mediation by IgG, and inhibition by antigenantibody complexes. J Immunol (1977) 118:2230-6.

184. Butterworth AE, David JR, Franks D, Mahmoud AAF, David PH, Sturrock RF, et al. Antibodydependent eosinophil-mediated damage to 51Cr-labeled schistosomula of Schistosoma mansoni: damage by purified eosinophils J Exp Med (1977) 145:136-50. doi:10.1084/jem.145.1.136

185. Capron M, Capron A. Effector functions of eosinophils in schistosomiasis. Mem Inst Oswaldo Cruz (1992) 87:167-70. doi:10.1590/S007402761992000800025

186. Swartz JM, Dyer KD, Cheever AW, Ramalingam T, Pesnicak L, Domachowske JB, et al. Schistosoma mansoni infection in eosinophil lineage-ablated mice. Blood (2006) 108:2420-7. doi:10.1182/blood2006-04-015933

187. Hogan SP, Rosenberg HF, Moqbel R, Phipps S, Foster PS, Lacy P, et al. Eosinophils: biological properties and role in health and disease. Clin Exp Allergy (2008) 38(5):70950. doi:10.1111/j.1365-2222.2008. 02958.x

188. Wu D, Molofsky AB, Liang H-E, Ricardo-Gonzalez RR, Jouihan HA, Bando JK, et al. Eosinophils sustain adipose alternatively activated macrophages associated with glucose homeostasis. Science (2011) 332:243-7. doi:10.1126/science. 1201475

189. Karasuyama H, Wada T, Yoshikawa S, Obata K. Emerging roles of basophils in protective immunity against parasites. Trends Immunol (2011) 32:125-30. doi:10.1016/j.it. 2010.11.006 
190. Demeure E, Rihet P, Abel L, Ouattara M, Bourgois A, Dessein AJ. Resistance to Schistosoma mansoni in humans: influence of the $\mathrm{IgE} / \mathrm{IgG} 4$ balance and IgG2 in immunity to reinfection after chemotherapy. I Infect Dis (1993) 168:1000-8. doi:10.1093/ infdis/ 168.4 .1000

191. Butterworth A, Dunne D, Fulford A, Capron M, Khalife J, Capron A, et al. Immunity in human schistosomiasis mansoni: cross-reactive $\mathrm{IgM}$ and $\mathrm{IgG} 2$ anti-carbohydrate antibodies block the expression of immunity. Biochimie (1988) 70:1053-63. doi:10.1016/0300-9084(88) 90268-4

192. Naus CW, Kimani G, Ouma JH, Fulford AJ, Webster M, van Dam GJ, et al. Development of antibody isotype responses to Schistosoma mansoni in an immunologically naive immigrant population: influence of infection duration, infection intensity, and host age. Infect Immun (1999) 67: 3444-51.

193. Naus CWA, Booth M, Jones FM, Kemijumbi J, Vennervald BJ, Kariuki $\mathrm{CH}$, et al. The relationship between age, sex, egg-count and specific antibody responses against Schistosoma mansoni antigens in a Ugandan fishing community. Trop Med Int Health (2003) 8:561-8. doi:10.1046/j.1365-3156. 2003.01056.x

194. Webster M, Fulford AJ, Braun G, Ouma JH, Kariuki HC, Havercroft JC, et al. Human immunoglobulin E responses to a recombinant 22.6kilodalton antigen from Schistosoma mansoni adult worms are associated with low intensities of reinfection after treatment. Infect Immun (1996) 64:4042-6.

195. Grzych JM, Grezel D, Xu CB, Neyrinck JL, Capron M, Ouma JH, et al. IgA antibodies to a protective antigen in human schistosomiasis mansoni. J Immunol (1993) 150:527-35.

196. Ganley-Leal LM, Mwinzi PNM, Cetre-Sossah CB, Andove J, Hightower AW, Karanja DMS, et al. Short report: higher percentages of circulating mast cell precursors correlate with susceptibility to reinfection with Schistosoma mansoni. Am J Trop Med Hyg (2006) 75:1053-7.

197. Grzych JM, Capron M, Dissous C, Capron A. Blocking activity of rat monoclonal antibodies in experimental schistosomiasis. J Immunol (1984) 133:998-1004.
198. Dunne DW, Butterworth AE, Fulford AJC, Ouma JH, Sturrock RF. Human IgE responses to Schistosoma mansoni and resistance to reinfection. Mem Inst Oswaldo Cruz (1992) 87:99-103. doi:10. 1590/S0074-02761992000800014

199. Khalife J, Capron M, Capron A, Grzych M, Butterworth AE, Dunne DW, et al. Immunity in human schistosomiasis mansoni: regulation of protective immune mechanisms by IgM blocking antibodies. J Exp Med (1986) 164:1626-40. doi:10.1084/jem.164.5.1626

200. Mwinzi PNM, Ganley-Leal L, Black CL, Secor WE, Diana MS, Colley DG. Circulating CD23+ B cell subset correlates with the development of resistance to Schistosoma mansoni reinfection in occupationally exposed adults who have undergone multiple treatments. $J$ Infect Dis (2009) 199:272-9. doi:10.1086/595792

201. Griffith QK, Liang Y, Onguru DO, Mwinzi PN, Ganley-Leal LM. CD23-bound IgE augments and dominates recall responses through human naive B cells. $J$ Immunol (2011) 186:1060-7. doi: 10.4049/jimmunol.1002709

202. Goes AM, Ramalho-Pinto FJ. Protective immunity to Schistosoma mansoni in mice is dependent on antibody and complement but not on radiosensitive leukocytes. Immunol Lett (1991) 28:5763. doi:10.1016/0165-2478(91) 90127-V

203. Zhou Y, Zhang H, Sun X-J, Zheng D, Liang Y-J, Luo J, et al. Murine CD8(+)T cell cytotoxicity against schistosomula induced by inoculation of schistosomal 22.6/26GST coupled Sepharose 4B beads. Vaccine (2012) 30:2440-7. doi:10. 1016/j.vaccine.2012.01.068

204. Riengrojpitak S, Anderson S, Wilson RA. Induction of immunity to Schistosoma mansoni: interaction of schistosomula with accessory leucocytes in murine skin and draining lymph nodes. Parasitology (1998) 117(Pt 4):301-9. doi: 10.1017/S0031182098003187

205. Wilson RA, Coulson PS. Immune effector mechanisms against schistosomiasis: looking for a chink in the parasite's armour. Trends Parasitol (2009) 25:423-31. doi:10. 1016/j.pt.2009.05.011

206. Kelly EA, Colley DG. In vivo effects of monoclonal anti-L3T4 antibody on immune responsiveness of mice infected with Schistosoma mansoni. Reduction of irradiated cercariae-induced resistance. J Immunol (1988) 140: 2737-45.

207. Bickle QD, Andrews BJ, Doenhoff MJ, Ford MJ, Taylor MG. Resistance against Schistosoma mansoni induced by highly irradiated infections: studies on species specificity of immunization and attempts to transfer resistance. Parasitology (1985) 90(Pt 2):301-12. doi:10. 1017/S0031182000051003

208. Moloney NA, Webbe G. Antibody is responsible for the passive transfer of immunity to mice from rabbits, rats or mice vaccinated with attenuated Schistosoma japonicum cercariae. Parasitology (1990) 100(Pt 2):235-9. doi:10.1017/S0031182000061230

209. Corrêa-Oliveira R, Caldas IR, Gazzinelli G. Natural versus druginduced resistance in Schistosoma mansoni infection. Parasitol Today (Regul Ed) (2000) 16:397-9. doi:10.1016/S0169-4758(00) 01740-3

210. Brito CF, Caldas IR, Coura Filho P, Correa-Oliveira R, Oliveira SC. $\mathrm{CD} 4+\mathrm{T}$ cells of schistosomiasis naturally resistant individuals living in an endemic area produce interferon-gamma and tumour necrosis factor-alpha in response to the recombinant 14KDA Schistosoma mansoni fatty acid-binding protein. Scand J Immunol (2000) 51:595-601. doi:10.1046/j.13653083.2000.00710.x

211. Ribeiro de Jesus A, Araújo I, Bacellar O, Magalhães A, Pearce E, Harn D, et al. Human immune responses to Schistosoma mansoni vaccine candidate antigens human immune responses to Schistosoma mansoni vaccine candidate antigens. Infect Immun (2000) 68:2797-803. doi:10.1128/IAI.68. $5.2797-2803.2000$

212. Gatlin MR, Black CL, Mwinzi PN, Secor WE, Karanja DM, Colley DG. Association of the gene polymorphisms IFN-gamma +874 , IL$13-1055$ and IL-4 -590 with patterns of reinfection with Schistosoma mansoni. PLoS Negl Trop Dis (2009) 3:e375. doi:10.1371/ journal.pntd.0000375

213. Omer-Ali P, Magee AI, Kelly C, Simpson AJG. A major role for carbohydrate epitopes preferentially recognized by chronically infected mice in the determination of Schistosoma mansoni schistosomulum surface antigenicity. J Immunol (1986) 137:3601-7.

214. Omer Ali P, Mansour M, Woody JN, Smithers SR, Simpson AJ.
Antibody to carbohydrate and polypeptide epitopes on the surface of schistosomula of Schistosoma mansoni in Egyptian patients with acute and chronic schistosomiasis. Parasitology (1989) 98(Pt 3):417-24. doi:10.1017/S0031182000061503

215. McVay CS, Tsung A, Appleton J. Participation of parasite surface glycoproteins in antibody-mediated protection of epithelial cells against Trichinella spiralis. Infect Immun (1998) 66:1941-5.

216. Appleton JA, Schain LR, McGregor DD. Rapid expulsion of Trichinella spiralis in suckling rats: mediation by monoclonal antibodies. Immunology (1988) 65: 487-92.

217. Peters PJ, Gagliardo LF, Sabin EA, Betchen AB, Ghosh K, Oblak JB, et al. Dominance of immunoglobulin G2c in the antiphosphorylcholine response of rats infected with Trichinella spiralis. Infect Immun (1999) 67:4661-7.

218. Harrison GBL, Pulford HD, Doolin EE, Pernthaner A, Shoemaker CB, Hein WR. Antibodies to surface epitopes of the carbohydrate larval antigen CarLA are associated with passive protection in strongylid nematode challenge infections. Parasite Immunol (2008) 30:577-84. doi:10.1111/j.1365-3024.2008. 01058.x

219. Lejoly-Boisseau H, Appriou M, Seigneur M, Pruvost A, TribouleyDuret J, Tribouley J. Schistosoma mansoni: in vitro adhesion of parasite eggs to the vascular endothelium. Subsequent inhibition by a monoclonal antibody directed to a carbohydrate epitope. Exp Parasitol (1999) 91:20-9. doi:10.1006/ expr.1999.4348

220. Dissous C, Capron A. Schistosoma mansoni: antigenic community between schistosomula surface and adult worm incubation products as a support for concomitant immunity. FEBS Lett (1983) 162:355-9. doi:10.1016/ 0014-5793(83)80787-X

221. Grzych J-M, Dissous C, Capron M, Torres S, Lambert P-H, Capron A. Schistosoma mansoni shares a protective carbohydrate epitope with keyhole limpet hemocyanin. J Exp Med (1987) 165:865-78. doi:10. 1084/jem.165.3.865

222. Grzych JM, Capron M, Lambert PH, Dissous C, Torres S, Capron A. An anti-idiotype vaccine against experimental 
schistosomiasis. Nature (1985) 316:74-6. doi:10.1038/316074a0

223. Nyame AK, Leppänen AM, Bogitsh BJ, Cummings RD. Antibody responses to the fucosylated LacdiNAc glycan antigen in Schistosoma mansoni-infected mice and expression of the glycan among schistosomes. Exp Parasitol (2000) 96:202-12. doi:10.1006/expr.2000. 4573

224. Nyame AK, Leppanen AM, DeBose-Boyd R, Cummings RD. Mice infected with Schistosoma mansoni generate antibodies to LacdiNAc (GalNAc $\beta 1 \rightarrow$ 4GlcNAc) determinants. Glycobiology (1999) 9:1029-35. doi:10.1093/glycob/9.10.1029

225. Harn DA, Mitsuyama M, David JR. Schistosoma mansoni antiegg monoclonal antibodies protect against cercarial challenge in vivo. J Exp Med (1984) 159:1371-87. doi:10.1084/jem.159.5.1371

226. van de Vijver KK, Hokke $\mathrm{CH}$, van Remoortere A, Jacobs W, Deelder AM, van Marck EA. Glycans of Schistosoma mansoni and keyhole limpet haemocyanin induce hepatic granulomas in vivo. Int J Parasitol (2004) 34:951-61. doi:10. 1016/j.ijpara.2004.04.009

227. van de Vijver KK, Deelder AM, Jacobs W, van Marck EA, Hokke CH. LacdiNAc- and LacNAccontaining glycans induce granulomas in an in vivo model for schistosome egg-induced hepatic granuloma formation. Glycobiology (2006) 16:237-43. doi:10. 1093/glycob/cwj058

228. van Roon A-MM, van de Vijver KK, Jacobs W, van Marck EA, van Dam GJ, Hokke $\mathrm{CH}$, et al. Discrimination between the anti-monomeric and the antimultimeric Lewis $\mathrm{X}$ response in murine schistosomiasis. Microbes Infect (2004) 6:1125-32. doi:10. 1016/j.micinf.2004.06.004

229. Wuhrer M, Koeleman CAM, Fitzpatrick JM, Hoffmann KF, Deelder AM, Hokke CH. Gender-specific expression of complex-type $\mathrm{N}$ glycans in schistosomes. Glycobioogy (2006) 16:991-1006. doi:10. 1093/glycob/cwl020

230. van Diepen A, Smit $\mathrm{CH}$, van Egmond L, Kabatereine NB, Pinot de Moira A, Dunne DW, et al. Differential anti-glycan antibody responses in Schistosoma mansoniinfected children and adults studied by shotgun glycan microarray. PLoS Negl Trop Dis (2012) 6: e1922. doi:10.1371/journal.pntd. 0001922
231. Heimburg-Molinaro J, Song X, Smith DF, Cummings RD. Preparation and analysis of glycan microarrays. In: Coligan JE, Dunn BM, Speicher DW, Wingfield PT, editors. Current Protocols in Protein Science. Hoboken, NJ: John Wiley \& Sons, Inc (2011). p. 1-33.

232. Song X, Heimburg-Molinaro J, Smith DF, Cummings RD. Derivatization of free natural glycans for incorporation onto glycan arrays: derivatizing glycans on the microscale for microarray and other applications. Curr Protoc Chem Biol (2011) 3: 53-63.

233. van Remoortere A, Vermeer HJ, van Roon AM, Langermans JA, Thomas AW, Wilson $\mathrm{RA}$, et al. Dominant antibody responses to Fucalpha1-3GalNAc and Fucalpha1-2Fucalpha13GlcNAc containing carbohydrate epitopes in Pan troglodytes vaccinated and infected with Schistosoma mansoni. Exp Parasitol (2003) 105:219-25. doi:10.1016/j.exppara.2003.12.005

234. Naus CWA, van Remoortere A, Ouma JH, Kimani G, Dunne DW, Kamerling JP, et al. Specific antibody responses to three schistosome-related carbohydrate structures in recently exposed immigrants and established residents in an area of Schistosoma mansoni endemicity. Infect Immun (2003) 71:5676-81. doi:10.1128/ IAI.71.10.5676-5681.2003

235. Kleij D, van der Tielens AGM, Yazdanbakhsh M. Recognition of schistosome glycolipids by immunoglobulin e: possible role in immunity. Infect Immun (1999) 67:5946-50.

236. de Boer AR, Hokke CH, Deelder AM, Wuhrer M. Serum antibody screening by surface plasmon resonance using a natural glycan microarray. Glycoconj J (2008) 25:75-84. doi:10.1007/ s10719-007-9100-x

237. Hewitson JP, Filbey KJ, Grainger JR, Dowle AA, Pearson M, Murray $\mathrm{J}$, et al. Heligmosomoides polygyrus elicits a dominant nonprotective antibody response directed against restricted glycan and peptide epitopes. J Immunol (2011) 187:4764-77. doi:10.4049/jimmunol.1004140

238. Omer Ali P, Smithers SR, Bickle Q, Phillips SM, Harn D, Simpson AJ. Analysis of the anti-Schistosoma mansoni surface antibody response during murine infection and its potential contribution to protective immunity. J Immunol (1988) 140:3273-9.

239. Keiser J, Utzinger J. Efficacy of current drugs against soiltransmitted helminth infections. JAMA (2008) 299:1937-48. doi:10. 1001/jama.299.16.1937

240. Booth M, Vounatsou P, Ngoran EK, Tanner M, Utzinger J. The influence of sampling effort and the performance of the Kato-Katz technique in diagnosing Schistosoma manson and hookworm co-infections in rural Cte dIvoire. Parasitology (2003) 127:525-31. doi:10.1017/S0031182003004128

241. Knopp S, Speich B, Hattendorf J, Rinaldi L, Mohammed KA, Khamis IS, et al. Diagnostic accuracy of Kato-Katz and FLOTAC for assessing anthelmintic drug efficacy. PLoS Negl Trop Dis (2011) 5:e1036. doi:10.1371/journal.pntd.0001036

242. Gryseels B, Polman K, Clerinx J, Kestens L. Human schistosomiasis. Lancet (2006) 368:1106-18. doi: 10.1016/S0140-6736(06)69440-3

243. Robijn MLM, Planken J, Kornelis D, Hokke CH, Deelder AM. Mass spectrometric detection of urinary oligosaccharides as markers of Schistosoma mansoni infection. Trans $\mathrm{R}$ Soc Trop Med Hyg (2008) 102:79-83. doi:10.1016/j. trstmh.2007.09.017

244. Vermeer HJ, van Dam GJ, Halkes KM, Kamerling JP, Vliegenthart JFG, Hokke $\mathrm{CH}$, et al. Immunodiagnostically applicable monoclonal antibodies to the circulating anodic antigen of Schistosoma mansoni bind to small, defined oligosaccharide epitopes. Parasitol Res (2003) 90:330-6. doi:10.1007/ s00436-003-0860-3

245. van Dam GJ, Wichers JH, Ferreira TMF, Ghati D, van Amerongen A, Deelder AM. Diagnosis of schistosomiasis by reagent strip test for detection of circulating cathodic antigen. J Clin Microbriol (2004) 42:5458-61. doi:10.1128/JCM.42. 12.5458-5461.2004

246. van Dam GJ, Claas FH, Yazdanbakhsh M, Kruize YC, van Keulen AC, Ferreira ST, et al. Schistosoma mansoni excretory circulating cathodic antigen shares Lewis- $x$ epitopes with a human granulocyte surface antigen and evokes host antibodies mediating complement-dependent lysis of granulocytes. Blood (1996) 88:4246-51.

247. Stothard JR, Sousa-Figueiredo JC, de Sousa-Figuereido JC, Betson
M, Adriko M, Arinaitwe M, et al. Schistosoma mansoni Infections in young children: when are schistosome antigens in urine, eggs in stool and antibodies to eggs first detectable? PLoS Negl Trop Dis (2011) 5:e938. doi:10.1371/ journal.pntd.0000938

248. Sousa-Figueiredo JC, Betson M, Kabatereine NB, Stothard JR. The urine circulating cathodic antigen (CCA) dipstick: a valid substitute for microscopy for mapping and point-of-care diagnosis of intestinal schistosomiasis. PLoS Negl Trop Dis (2013) 7:e2008. doi:10.1371/ journal.pntd.0002008

249. Van Dam GJ, de Dood CJ, Lewis M, Deelder AM, van Lieshout L, Tanke HJ, et al. (2013). A robust dry reagent lateral flow assay for diagnosis of active schistosomiasis by detection of Schistosoma circulating anodic antigen. Exp Parasitol 135(2):274-82. doi:10.1016/ j.exppara.2013.06.017

250. Robijn MLM, Koeleman CAM, Wuhrer M, Royle L, Geyer R, Dwek RA, et al. Targeted identification of a unique glycan epitope of Schistosoma mansoni egg antigens using a diagnostic antibody. Mol Biochem Parasitol (2007) 151: 148-61. doi:10.1016/j.molbiopara. 2006.10.019

251. Robijn MLM, Koeleman CAM, Hokke CH, Deelder AM. Schistosoma mansoni eggs excrete specific free oligosaccharides that are detectable in the urine of the human host. Mol Biochem Parasitol (2007) 151:162-72. doi:10.1016/j. molbiopara.2006.10.018

252. Forbes LB, Appleyard GD, Gajadhar AA. Comparison of synthetic antigen excretory-secretory antigen for the detection of trichinellosis in swine using enzymelinked immunosorbent assay. $J$ Parasitol (2004) 90:835-40. doi:10. 1645/GE-187R

253. Kouguchi H, Matsumoto J, Yamano K, Katoh Y, Oku Y, Suzuki T, et al. Echinococcus multilocularis: purification and characterization of glycoprotein antigens with serodiagnostic potential for canine infection. Exp Parasitol (2011) 128:50-6. doi:10.1016/j.exppara.2011.02.002

254. Koizumi A, Yamano K, Schweizer F, Takeda T, Kiuchi F, Hada N. Synthesis of the carbohydrate moiety from the parasite Echinococcus multilocularis and their antigenicity against human sera. Eur J Med Chem (2011) 46:1768-78. doi:10.1016/j.ejmech.2011.02.030 
255. Díaz A, Fontana EC, Todeschini AR, Soulé S, González H, Casaravilla $\mathrm{C}$, et al. The major surface carbohydrates of the Echinococcus granulosus cyst: mucin-type O-glycans decorated by novel galactose-based structures. Biochemistry (2009) 48:11678-91. doi:10.1021/bi901112q

256. Aranzamendi C, Tefsen B, Jansen M, Chiumiento L, Bruschi F, Kortbeek T, et al. Glycan microarray profiling of parasite infection sera identifies the LDNF glycan as a potential antigen for serodiagnosis of trichinellosis. Exp Parasitol (2011) 129:221-6. doi:10.1016/j. exppara.2011.08.015

257. van Stijn CM, van denBroek M, Vervelde L, Alvarez RA, Cummings RD, Tefsen B, et al. Vaccination-induced IgG response to Galalpha1-3GalNAc glycan epitopes in lambs protected against Haemonchus contortus challenge infection. Int $J$ Parasitol (2010) 40:215-22. doi:10.1016/j.ijpara.2009.07.009

258. Wang W, Wang L, Liang Y-S. Susceptibility or resistance of praziquantel in human schistosomiasis: a review. Parasitol Res (2012) 111:1871-7. doi:10.1007/s00436012-3151-Z

259. Steinmann P, Zhou X-N, Du ZW, Jiang J-Y, Xiao S-H, Wu Z-X, et al. Tribendimidine and albendazole for treating soil-transmitted helminths, Strongyloides stercoralis and Taenia spp.: open-label randomized trial. PLoS Negl Trop Dis (2008) 2:e322. doi:10.1371/ journal.pntd.0000322

260. Sripa B, Hong S-T. Tribendimidine: an alternative anthelmintic for liver flukes? Lancet Infect Dis (2011) 11:77-8. doi:10.1016/ S1473-3099(10)70289-9

261. Hu Y, Xiao S-H, Aroian RV. The new anthelmintic tribendimidine is an L-type (levamisole and pyrantel) nicotinic acetylcholine receptor agonist. PLoS Negl Trop Dis (2009) 3:e499. doi:10.1371/ journal.pntd.0000499

262. McManus DP, Loukas A. Current status of vaccines for schistosomiasis. Clin Microbiol Rev (2008) 21:225-42. doi:10.1128/ CMR.00046-07

263. Riveau G, Deplanque D, Remoué F, Schacht A-M, Vodougnon $\mathrm{H}$, Capron M, et al. Safety and immunogenicity of rSh28GST antigen in humans: phase 1 randomized clinical study of a vaccine candidate against urinary schistosomiasis. PLoS
Negl Trop Dis (2012) 6:e1704. doi:10.1371/journal.pntd.0001704

264. Kupferschmidt K. Coming at a Snail's Pace. Science (2013) 339:502-3. doi:10.1126/science.339.6119.502

265. Bethony JM, Simon G, Diemert DJ, Parenti D, Desrosiers A, Schuck $\mathrm{S}$, et al. Randomized, placebocontrolled, double-blind trial of the Na-ASP-2 hookworm vaccine in unexposed adults. Vaccine (2008) 26:2408-17. doi:10.1016/j. vaccine.2008.02.049

266. Diemert DJ, Pinto AG, Freire J, Jariwala A, Santiago H, Hamilton $\mathrm{RG}$, et al. Generalized urticaria induced by the Na-ASP-2 hookworm vaccine: implications for the development of vaccines against helminths. J Allergy Clin Immunol (2012) 130:169-76.e6. doi:10.1016/j.jaci.2012.04.027

267. Bethony J, Loukas A, Smout M, Brooker S, Mendez S, Plieskatt J, et al. Antibodies against a secreted protein from hookworm larvae reduce the intensity of hookworm infection in humans and vaccinated laboratory animals. FASEB J (2005) 19:1743-5.

268. van Balkom BW, van Gestel RA, Brouwers JF, Krijgsveld J, Tielens AG, Heck AJ, et al. Mass spectrometric analysis of the Schistosoma mansoni tegumental sub-proteome. J Proteome Res (2005) 4(3):958-66. doi:10.1021/ pr050036w

269. Mulvenna J, Sripa B, Brindley PJ, Gorman J, Jones MK, Colgrave ML, et al. The secreted and surface proteomes of the adult stage of the carcinogenic human liver fluke Opisthorchis viverrini. Proteomics (2010) 10: 1063-78. doi:10.1002/pmic. 200900393

270. Braschi S, Wilson RA. Proteins exposed at the adult schistosome surface revealed by biotinylation. Mol Cell Proteomics (2006) 5: 347-56.

271. van Remoortere A, Hokke $\mathrm{CH}$, van Dam GJ, van Die I, Deelder AM, van den Eijnden DH. Various stages of schistosoma express Lewis $x$, LacdiNAc, GalNAc $\beta 1-4$ (Fuc $\alpha 1-3)$ GlcNAc and GalNAc $\beta 1$ 4(Fuc $\alpha$ 1-2Fuc $\alpha$ 1-3)GlcNAc carbohydrate epitopes: detection with monoclonal antibodies that are characterized by enzymatically synthesized neoglycoproteins. Glycobiology (2000) 10:601-9. doi:10.1093/glycob/10.6.601

272. Vervelde L, Bakker N, Kooyman FN, Cornelissen AW, Bank CM,
Nyame AK, et al. Vaccinationinduced protection of lambs against the parasitic nematode Haemonchus contortus correlates with high IgG antibody responses to the LDNF glycan antigen. Glycobiology (2003) 13:795-804. doi:10.1093/glycob/cwg107

273. Meyvis Y, Callewaert N, Gevaert K, Timmerman E, van Durme J, Schymkowitz J, et al. Hybrid $\mathrm{N}$-glycans on the host protective activation-associated secreted proteins of Ostertagia ostertag and their importance in immunogenicity. Mol Biochem Parasitol (2008) 161:67-71. doi:10.1016/j. molbiopara.2008.05.004

274. Taylor CE, Cobb BA, RittenhouseOlson K, Paulson JC, Schreiber JR. Carbohydrate moieties as vaccine candidates: targeting the sweet spot in the immune response. $\mathrm{Vac}$ cine (2012) 30:4409-13. doi:10. 1016/j.vaccine.2012.04.090

275. Peterson NA, Hokke CH, Deelder AM, Yoshino TP. Glycotope analysis in miracidia and primary sporocysts of Schistosoma mansoni: differential expression during the miracidium-to-sporocyst transformation. Int $J$ Parasito (2009) 39:1331-44. doi:10.1016/j. ijpara.2009.06.002

276. Cummings RD, Nyame AK. Glycobiology of schistosomiasis. FASEB J (1996) 10:838-48.

277. Nyame AK, Yoshino TP, Cummings RD. Differential expression of LacdiNAc, fucosylated LacdiNAc, and Lewis $\mathrm{x}$ glycan antigens in intramolluscan stages of Schistosoma mansoni. J Parasitol (2002) 88:890-7. doi:10.1645/0022-3395(2002) 088[0890:DEOLFL]2.0.CO;2

278. Loker ES, Bayne CJ. Molecular studies of the molluscan response to digenean infection. $A d v$ Exp Med Biol (2001) 484:209-22. doi: 10.1007/978-1-4615-1291-2_20

279. Yoshino TP, Boyle JP, Humphries JE. Receptor-ligand interactions and cellular signalling at the host-parasite interface. Parasitology (2001) 123(Suppl): S143-57. doi:10.1017/ S0031182001007685

280. Castillo MG, Wu X-J, Dinguirard $\mathrm{N}$, Nyame AK, Cummings RD, Yoshino TP. Surface membrane proteins of Biomphalaria glabrata embryonic cells bind fucosyl determinants on the tegumental surface of Schistosoma mansoni primary sporocysts. J Parasitol (2007) 93:832-40. doi:10.1645/ GE-954R.1
281. Yoshino TP, Dinguirard N, Kunert J, Hokke $\mathrm{CH}$. Molecular and functional characterization of a tandem-repeat galectin from the freshwater snail Biomphalaria glabrata, intermediate host of the human blood fluke Schistosoma mansoni. Gene (2008) 411: 46-58. doi:10.1016/j.gene.2008. 01.003

282. Lehr T, Beuerlein $\mathrm{K}$, Doenhoff MJ, Grevelding CG, Geyer R. Localization of carbohydrate determinants common to Biomphalaria glabrata as well as to sporocysts and miracidia of Schistosoma mansoni. Parasitology (2008) 135:931-42. doi:10.1017/ S0031182008004514

283. Hokke CH, Deelder AM, Hoffmann KF, Wuhrer M. Glycomics-driven discoveries in schistosome research. Exp Parasitol (2007) 117:275-83. doi:10.1016/j.exppara.2007.06.003

284. Yoshino TP, Wu X-J, Liu H, Gonzalez LA, Deelder AM, Hokke $\mathrm{CH}$. Glycotope sharing between snail hemolymph and larval schistosomes: larval transformation products alter shared glycan patterns of plasma proteins. PLoS Negl Trop Dis (2012) 6: e1569. doi:10.1371/journal.pntd. 0001569

285. Thomas CJ, Schroder K. Pattern recognition receptor function in neutrophils. Trends Immunol (2013) 34:317-28. doi:10.1016/j.it. 2013.02.008

286. Adema CM, Hertel LA, Miller RD, Loker ES. A family of fibrinogenrelated proteins that precipitates parasite-derived molecules is produced by an invertebrate after infection. Proc Natl Acad Sci U S A (1997) 94:8691-6. doi:10.1073/pnas.94.16.8691

287. Wu X, Sabat G, Brown JF, Zhang M, Taft A, Harms A, et al. Proteomic analysis of Schistosoma mansoni proteins released during in vitro miracidium-tosporocyst transformation. $\mathrm{Mol}$ Biochem Parasitol (2009) 164: 32-44. doi:10.1016/j.molbiopara. 2008.11.005

288. Roger E, Grunau C, Pierce RJ, Hirai H, Gourbal B, Galinier R, et al. Controlled chaos of polymorphic mucins in a metazoan parasite (Schistosoma mansoni) interacting with its invertebrate host (Biomphalaria glabrata). PLoS Negl Trop Dis (2008) 2:e330. doi:10.1371/ journal.pntd.0000330

289. Kawar ZS, Haslam SM, Morris HR, Dell A, Cummings RD. Novel 
poly-GalNAcbeta1-4GlcNAc (LacdiNAc) and fucosylated polyLacdiNAc N-glycans from mammalian cells expressing beta1,4$\mathrm{N}$-acetylgalactosaminyltransferase and alpha1,3-fucosyltransferase. $J$ Biol Chem (2005) 280(13):128109. doi:10.1074/jbc.M414273200

Conflict of Interest Statement: The authors declare that the research was conducted in the absence of any commercial or financial relationships that could be construed as a potential conflict of interest.

Received: 15 May 2013; accepted: 03 August 2013; published online: 28 August 2013.

Citation: Prasanphanich NS, Mickum $M L, \quad H e i m b u r g-M o l i n a r o \quad J$ and
Cummings RD (2013) Glycoconjugates in host-helminth interactions. Front. Immunol. 4:240. doi: 10.3389/fimmu.2013.00240

This article was submitted to Molecular Innate Immunity, a section of the journal Frontiers in Immunology.

Copyright (C) 2013 Prasanphanich, Mickum, Heimburg-Molinaro and

Cummings. This is an open-access article distributed under the terms of the Creative Commons Attribution License (CC BY). The use, distribution or reproduction in other forums is permitted, provided the original author(s) or licensor are credited and that the original publication in this journal is cited, in accordance with accepted academic practice. No use, distribution or reproduction is permitted which does not comply with these terms. 